\title{
11 Stylophora pistillata-A Model Colonial Species in Basic and Applied Studies
}

\author{
Dor Shefy and Baruch Rinkevich
}

\section{CONTENTS}

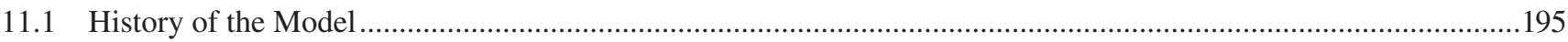

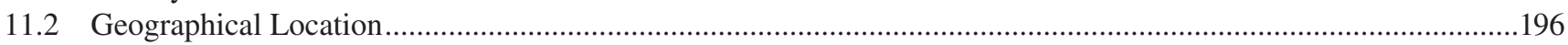

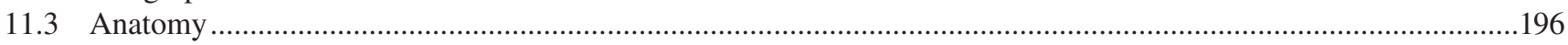

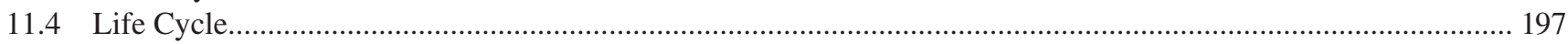

11.4.1 Sexual Reproduction, Seasonality and General Reproductive Characteristics ....................................... 197

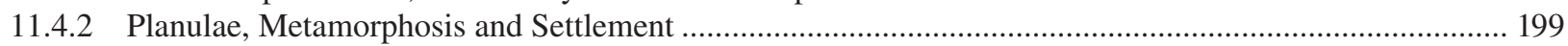

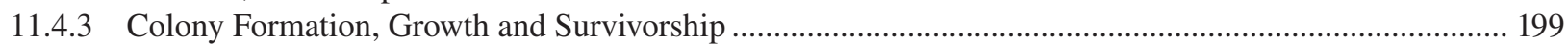

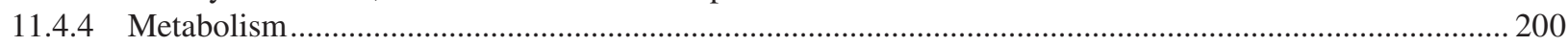

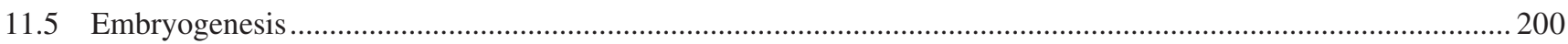

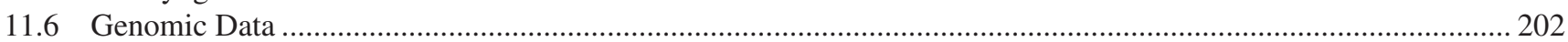

11.7 Functional Approaches: Tools for Molecular and Cellular Analyses.............................................................. 202

11.7.1 The Use of S. pistillata as a Model Species in Studies on Climate Change

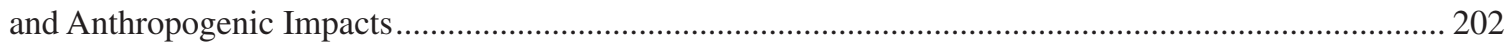

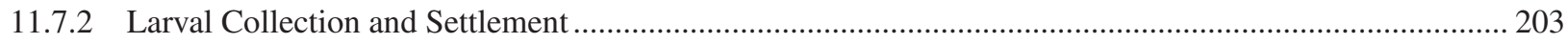

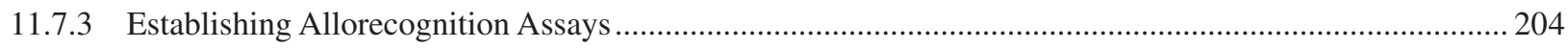

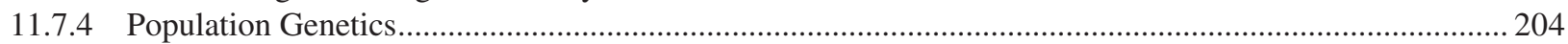

11.7.5 Establishing S. pistillata as a Model Orgnism for Reef Restoration.................................................... 205

11.8 Challenging Questions Both in Academic and Applied Research ................................................................ 205

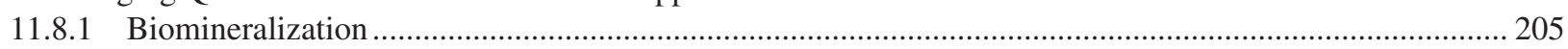

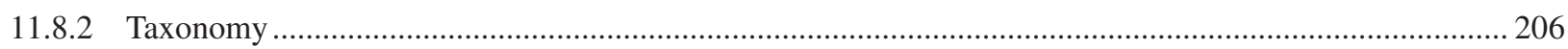

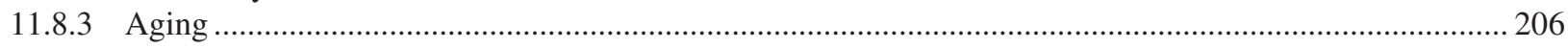

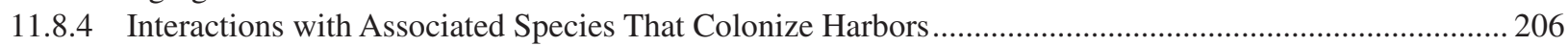

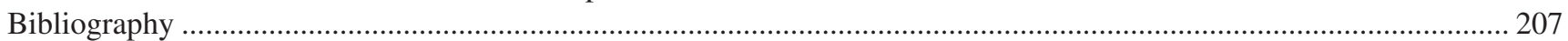

\subsection{HISTORY OF THE MODEL}

Stylophora pistillata (Pocilloporidae; Scleractinia) is a common Indo-Pacific branching coral species, also known by the common name smooth cauliflower coral (Figures 11.1, 11.2, 11.3). This species was first named more than 220 years ago as Madrepora pistillata (Esper 1797) (Figure 11.1a), which was followed by many synonymous names in this period, until it stabilized on the current name. To the best of our knowledge, the first focused study on the biology of this species was engaged with sexual reproduction, settlement and metamorphosis in Palau's colonies (Atoda 1947a). Three decades later, Loya (1976) referred to some ecological attributes of this species and suggested that $S$. pistillata from the Red Sea is an "r strategist" species. This work was followed by a wide range of studies, with most performed on S. pistillata populations from the Gulf of Aqaba/Eilat (GOA/E; Red Sea) along the Israeli coast. The studies in the late 1970s and early 1980s were focused on the species' reproductive activities and the impacts of oil pollution on sexual reproduction (Loya and Rinkevich 1979;
Rinkevich and Loya 1977, 1979a, 1979b, 1979c, 1985b, 1987), allorecognition and ecological interactions (Mokady et al. 1991; Edwards and Emberton 1980; Müller et al. 1984; Rinkevich and Loya 1983a, 1985a; Rinkevich et al. 1991, 1993; Rinkevich and Weissman 1987), as on basic coral physiology, pattern formation and senescence (Dubinsky et al. 1984, 1990; Falkowski and Dubinsky 1981; Falkowski et al. 1984; Loya and Rinkevich 1987; Muscatine et al. 1984, 1985, 1989; Rinkevich 1989; Weis et al. 1989; McCloskey and Muscatine 1984; Rahav et al. 1989; Rinkevich and Loya 1983b, 1983c, 1984a, 1984b, 1986). From the late 80 s, more and more studies have focused on $S$. pistillata as a model species in search of a wide range of biological queries, all over the Indo-Pacific area and as an important, sometimes key, species in reef assemblages. Following the observations on coral bleaching events and the high mortality rates that have been documented globally, more attention has been devoted to $S$. pistillata's metabolism, nutrient uptake and interaction with environmental drivers, making this species a model species for studying the complex interactions between the animal, its symbiotic algae and the 
environment (Abramovitch-Gottlib et al. 2003; Dubinsky et al. 1990; Dubinsky and Jokiel 1994; Ferrier-Pagès et al. 2000, 2001, 2003, 2010; Franklin et al. 2004; Grover et al. 2002, 2003, 2006, 2008; Hoegh-Guldberg and Smith 1989a, 1989b; Houlbrèque et al. 2003, 2004; Lampert-Karako et al. 2008; Muscatine et al. 1989; Nakamura et al. 2003; Rahav et al. 1989; Rinkevich 1989; Shashar et al. 1993; Tchernov et al. 2004; Titlyanov et al. 2000a; Titlyanov et al. 2000b; Titlyanov et al. 2001; Weis et al. 1989). The accumulated knowledge on the species distribution and the reproductive mode of S. pistillata has led researchers to study population dynamics, population genetic structures, modes of reproduction and larval dispersal in a specific reef and among reefs (Ayre and Hughes 2000; Zvuloni et al. 2008; Klueter and Andreakis 2013; Douek et al. 2011; Guerrini et al. 2020; Takabayashi et al. 2003; Nishikawa et al. 2003). $S$. pistillata colonies are also often used for understanding the impacts of anthropogenic activities and climate change disturbances on coral reefs and, together with the rapid advances in technology, scientists have examined the combined effects of anthropogenic/climate change impacts on $S$. pistillata's biological and ecological parameters (Ammar et al. 2012; Guerrini et al. 2020; Horwitz et al. 2017; Loya and Rinkevich 1979; Shefy et al. 2018; Tamir et al. 2020), physiology (Abramovitch-Gottlib et al. 2003; Banc-Prandi and Fine 2019; Bellworthy and Fine 2017; Bellworthy et al. 2019; Dias et al. 2019; Epstein et al. 2005; Fitt et al. 2009; Grinblat et al. 2018; Hall et al. 2018; Hawkins et al. 2015; HoeghGuldberg and Smith 1989b; Krueger et al. 2017; Reynaud et al. 2003; Rinkevich et al. 2005; Rosic et al. 2020; Sampayo et al. 2008; Sampayo et al. 2016; Saragosti et al. 2010; Shick et al. 1999; Stat et al. 2009) and gene expression patterns (Maor-Landaw and Levy 2016; Oren et al. 2010, 2013; Voolstra et al. 2017). Several studies have focused on in vitro approaches with S. pistillata cells and minute fragments for the development of novel methodologies; cell culture, nubbin and larvae usage for ecotoxicology and for reef restoration and for the elucidation of biological features, such as calcification and algal movements (Bockel and Rinkevich 2019; Danovaro et al. 2008; Downs et al. 2014; Epstein et al. 2000; Frank et al. 1994; Horoszowski-Fridman et al. 2020; Mass et al. 2012, 2017a; Raz-Bahat et al. 2006; Shafir et al. 2001, 2003, 2007, 2014); on anatomical features (Raz-Bahat et al. 2017); and on applied approaches (Rinkevich 2015a; Rinkevich and Shafir 1998; Rinkevich et al. 1999; Shafir et al. 2001). The understanding that coral reefs around the world are degrading has led, in the last two decades, to the development of an additional applied route, an active reef restoration that is based on a wide range of methodologies being tested on S. pistillata as a model species (Amar and Rinkevich 2007; Epstein and Rinkevich 2001 Epstein et al. 2001, 2005; Golomb et al. 2020; Horoszowski-Fridman et al. 2015, 2020; Horoszowski-Fridman and Rinkevich 2020; Linden and Rinkevich 2011, 2017; Linden et al. 2019; Rachmilovitz and Rinkevich 2017; Rinkevich 2000, 2015a, 2019a, 2019b; Shafir and Rinkevich 2008, 2010; Shafir et al. 2006a, 2009).
Here, we aim to review the knowledge about $S$. pistillata's biological features in various scientific disciplines for the last eight decades of research.

\subsection{GEOGRAPHICAL LOCATION}

S. pistillata colonies are found in shallow waters and up to 70 meters deep (Fishelson 1971; Kramer et al. 2019; Muir and Pichon 2019; Veron 2000). This species has a wide geographical range in the tropical and sub-tropical Indo-Pacific Ocean; central and west Pacific; tropical Australia; South China Sea; southern Japan; central Indian Ocean; southwest and northwest Indian Ocean; Arabian/Iranian Gulf; Gulf of Aden and the Red Sea, including the gulfs of Suez and Aqaba/Eilat (Veron 2000).

\subsection{ANATOMY}

An S. pistillata colony consists of up to tens of thousands of polyps at adulthood, each about 1-2 $\mathrm{mm}$ in diameter, where each polyp creates a small skeletal cup (termed a corallite), the hard supporting blueprint of the polyp's tissue (Veron 2000). The external soft tissues of the polyps and their extensions that connect between the polyps (coenosarc) overlie the coral skeleton that is made of calcium carbonate (Veron 2000). The polyps are anchored to the underlying skeletons by cells called desmocytes that connect the lower ectodermic layer (the calicoblastic layer) to the perforated calcium carbonate milieu (Muscatine et al. 1997; Raz-Bahat et al. 2006; Tambutté et al. 2007). Each polyp is a hollow cylindrical blind-ended sac that resembles a sea anemone in structure with a mouth in the center of the polyp, surrounded by 12 hollow retractable tentacles (Figure 11.2d) that connect to the gastric cavity by the pharynx. This is the gateway for food particles to the coelenteron, but studies revealed further roles in chemical digestion (Raz-Bahat et al. 2017). All polyps within a colony are connected to each other via a network of cell-lined tubes (gastrovascular canals) that radiate from the gastric cavity of the polyps. The polyp's internal gastric cavity is divided by 12 partitions (mesenteries; 6 are complete) into compartments which run radially from the body wall's gastrodermis to the actinopharynx and are connected to the pharynx carrying six long extensions (mesenterial filaments; Raz-Bahat et al. 2017). Two types of mesenterial filaments exist in S. pistillata, distinct, as much to be known by general morphology: four short filaments with no secretory cells and two long convoluted filaments with stinging and secretory cells (Raz-Bahat et al. 2017) that penetrate the gastric cavity and into the gastrovascular canals. The compartments between the mesenteries are also the sites where male and female gonads are developed (Ammar et al. 2012; Rinkevich and Loya 1979a). As in all corals, each polyp and the connected coenosarc consist of two epithelial layers, the ectodermic and gastrodermis (endodermis), separated by the mesoglea. This non-epithelial milieu binds the two epithelial layers together throughout the colony while consisting of a gelatinous substance, with collagen fibers 
and some cells. The columnar ectodermic layer contains mucus gland cells, nematocytes and spyrocyte cells, and the gastrodermis layer contains the zooxanthellae (Al-Sofyani 1991; Raz-Bahat et al. 2017, Bockel and Rinkevich 2019). The tentacles that are located above the oral disk are loaded with zooxanthellae in their gastrodermis cells, while the epidermis contains nematocytes.

As mentioned, the skeleton is secreted by the calicoblastic tissue (also named calicodermis), which forms the lower ectodermal layer (Allemand et al. 2004, 2011). The calicoblastic epithelium is very thin and has only calicoblastic cells anchored to the skeleton by the desmocytes (RazBahat et al. 2006; Tambutté et al. 2007). The calicoblastic epithelium secretes amorphous nano-calcium carbonate crystals into microenvironments enriched in organic material. The carbonate crystals aggregate and then crystallize to create ordered aragonitic structures (Mass et al. 2017b; Von Euw et al. 2017). On the coenosteum (skeleton secreted by the coenosarc), skeletal spines called coenosteal spines are developed, and in shallow water colonies, they have granular textures as compared to smoother textures in deeper water colonies (Malik et al. 2020).

\subsection{LIFE CYCLE}

\subsubsection{Sexual Reproduction, Seasonality and General Reproductive Characteristics}

While most of the coral species are broadcast spawners, together with other 61 species, S. pistillata belongs to a group of brooding coral species, where fertilization and larval development take place inside the polyps (Ammar et al. 2012; Fan and Dai 2002; Rinkevich and Loya 1979a) for an estimated duration of two weeks (Fan and Dai 2002; Shefy et al. 2018). The planula larvae are released to the water column about one to two hours after sunset (Atoda 1947a; Rinkevich and Loya 1979b)

S. pistillata is a hermaphrodite species, and male and female gonads are situated side by side within the polyp's coelenteron, extended into the body cavities and attached to the mesenteries by stalks. Along astogeny, the male gonads appear first when the colonies reach an approximate radius of $2 \mathrm{~cm}$, and female gonads develop a year later (Rinkevich and Loya 1979a). A wide range of anthropogenic and natural stressors may affect gonadal development. Early studies revealed that oil pollution and sedimentation directly reduce male and female gonad numbers and significantly affect the developing planulae (Loya and Rinkevich 1979; Rinkevich and Loya 1979c). Even nutrient-enriched environments may affect gonads and larval development, and while phosphorus load may have a minor impact on the reproductive efforts (Ammar et al. 2012), particulate matter (PM) and particulate organic matter (POM) may increase the size and number of oocytes and testes (Bongiorni et al. 2003a 2003b). Yet, resident fish within coral colonies that secrete nutrients (Liberman et al. 1995) do not have impacts on fecundity, as on the colony color morph (Rinkevich 1982). In contrast, intraspecific (within the same species) and interspecific (with different species) interactions have impacts on the number of female gonads per polyp (Rinkevich and Loya 1985b).

S. pistillata's reproductive patterns, seasonality and reproductive efforts vary among bio-geographical regions. In Palau, Atoda (1947a) recorded planulae release one to two weeks after a full moon all year long. Differences in seasonality are also present in the population at Yabnu (South Res Sea) and Tarut Bay (Arabian Gulf), which are in the same latitude but in different seas. In Tarut Bay, embryos were observed for just two months a year (before seawater temperature exceeded $31^{\circ} \mathrm{C}$ ), while in Yabnu, embryos were documented ten months a year (before temperature exceeded $29^{\circ} \mathrm{C}$ ) (Fadlallah and Lindo 1988). In the Philippines, the reproductive season of $S$. pistillata lasts just three months, from November to January (Baird et al. 2015), while in Taiwan, documentations revealed allyear-round larval release, with no obvious lunar periodicity (Fan and Dai 2002). S. pistillata colonies in the southern hemisphere release planulae from August to December in the Great Barrier Reef (GBR) (Tanner 1996) and from August to May with lunar periodicity in south Australia (Villanueva et al. 2008).

The reproduction of the $S$. pistillata populations in the Gulf of Aqaba/Eilat, Red Sea, is a model case for coral reproduction for over five decades, allowing a glimpse of changes in reproduction on an extended time scale. During the 1970s and 1980s, shallow-water S. pistillata colonies in Eilat released planulae for seven to eight months (December-July) (Rinkevich and Loya 1979b, 1987). Recent observations revealed that seasonality of larval release during the 2010s is extended by one to two months, from December to September-October (Rinkevich and Loya 1979b, 1987; Shefy et al. 2018) and year-round recruitment (Guerrini et al. 2020). Studies also revealed a bell-shaped curve in the larval release of most S. pistillata populations characterized in Eilat by an increase in planulae numbers until reaching a peak and then, in the second half, a decrease in the release until the end of the season (Amar et al. 2007; Fan and Dai 2002; Rinkevich and Loya 1979a, 1979b, 1987; Shefy et al. 2018; Tanner 1996). Fecundity among different colonies (even those of the same size that are situated side by side in the reef) or within a coral colony over several reproductive seasons is portrayed by high variability (Rinkevich and Loya 1987; Shefy et al. 2018). Variation is also recorded for lunar periodicity that was assigned for some populations (Atoda 1947a; Dai et al. 1992; Fan and Dai 2002; Tanner 1996; Villanueva et al. 2008; Zakai et al. 2006) while missing in others (Linden et al. 2018; Rinkevich and Loya 1979b). Linden et al. (2018) revealed that larval release by S. pistillata colonies does not comply with the assumed entrainment by the lunar cycle, further documenting that the lunar cycle does not provide a strict zeitgeber and can better be classified as a circatrigintan pattern. Water temperature and solar radiation did not correlate significantly with larval release. 

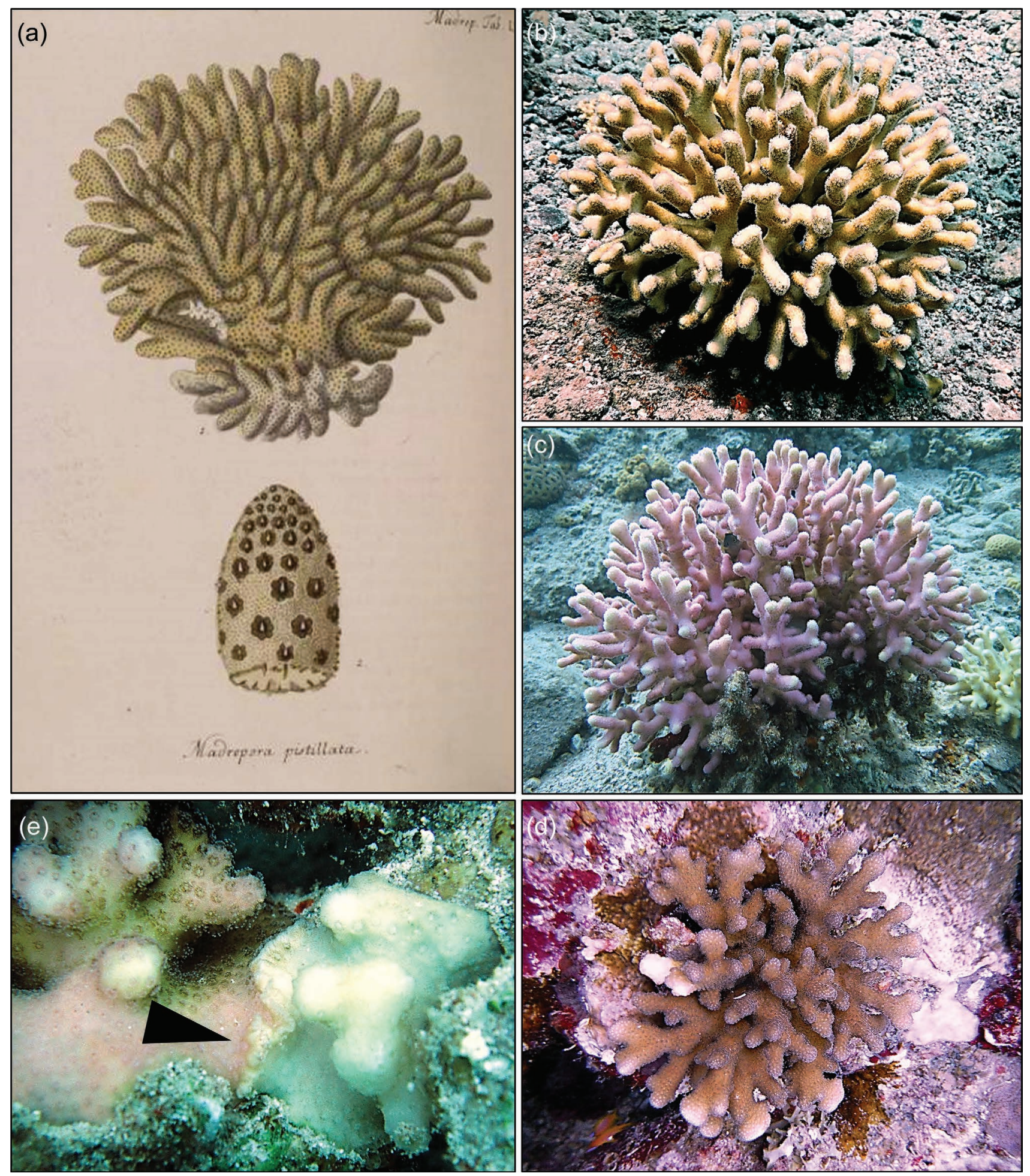

FIGURE 11.1 (a) The first description from 1797 of Stylophora pistillata (assigned the name Madrepora pistillata) by Eugenius Johann Christoph Esper in his book: Fortsetzungen der Pflanzenthiere in Abbildungennach der Natur mit Farben erleuchtet nebst Beschreibungen. (b-c) S. pistillata colonies representing two common color morphs (Gulf of Aqaba/Eilat). (d) The S. danae morphotype of S. pistillata (South Sinai, Red Sea; following Stefani et al. 2011). (e) Two juvenile colonies in allogeneic contact, rejecting each other (sensu Rinkevich and Loya 1983a) marked by the black arrowhead. (Photographs [b-e] courtesty of D. Shefy.) 


\subsubsection{Planulae, Metamorphosis and Settlement}

Without an efficient sexual reproduction process and successful settlement (recruitment) of coral larvae, a coral reef will not grow and thrive. For recruitment, the planula larvae need to find suitable substrates to settle and to develop. The ball-shaped planulae are released from the polyp mouths of shallow water $S$. pistillata colonies with the oral part upward and then alter to 1-2-mm-long rodlike-shaped swimming larvae (Figure 11.2a, b; Rinkevich and Loya 1979a). Planulae from mesophotic colonies are smaller than shallow-water planulae, contain different symbiont clades and have lower GFP-like chromoprotein mRNA expression (Scucchia et al. 2020; Rinkevich and Loya 1979a; Byler et al. 2013; Lampert-Karako et al. 2008; Winters et al. 2009). Planulae are released to the water loaded with zooxanthellae inherited from the mother colony (vertical transmission) but can also acquire zooxanthellae from the water column (horizontal transmission) (Byler et al. 2013).

Similar to other Pocilloporidae species, the planulae of $S$. pistillata settle within a few hours upon release, with the majority settling in the first 48 hours upon release (Amar et al. 2007; Atoda 1947a; Atoda 1947b; Atoda 1951; Nishikawa et al. 2003; Richmond 1997; Wallace and Harrison 1990). Unlike other coral species, these planulae settle and metamorphose on any available substrate, including natural hard layers, manmade and fabricated substrates (glass, plastic, metal, concrete, etc.), such as on water upper-surface tension layers under laboratory conditions (Nishikawa et al. 2003; Putnam et al. 2008; Rinkevich and Loya 1979a), and metamorphose to primary polyps, even without the presence of crustose coralline algae (CCA) or preconditioned biofilm (Amar et al. 2007; Atoda 1947a; Baird and Morse 2004; Heyward and Negri 1999; Nishikawa et al. 2003; Putnam et al.2008; Rinkevich and Loya 1979a). In Eilat, Red Sea, year-round recruitment has recently been documented (Guerrini et al. 2020). Planulae settlement is associated with mucus secretion from aboral epidermal cells, followed by flattened larvae that form disc-like shapes and the completion of basal plates carrying 24 basal ridges toward the formation of columellas three to four days post-settlement (Baird and Babcock 2000). Planulae settle either separate from each other or in aggregates, a distribution setting that leads to allogeneic contacts between adjacent spat either to morphological fusions into coral chimeras or allogeneic rejections characterized by necrotic areas and pseudo-fusion events (Figure 11.1e; Amar et al. 2007; Frank et al. 1997; Linden and Rinkevich 2017; Raymundo and Maypa 2004; Rinkevich 2011). Aggregated settlement and chimerism have further been documented in other marine invertebrates and are claimed to benefit coral chimeras through an immediate increase in colonial size and survival rates (Amar et al. 2008; Puill-Stephan et al. 2012; Raymundo and Maypa 2004; Rinkevich 2019b).

\subsubsection{Colony Formation, Growth AND SURVIVORSHIP}

Colonial astogeny occurs through iterated polyp buddings, with an axially rod-like growth form of branches where each branch consists of numerous small polyps, with a colonial symmetry that approximates a sphere (Loya 1976), all configured by a pre-designed colonial architecture (Rinkevich 2001, 2002) and nutritional resources that provide positional information for colonial structures (Kücken et al. 2011). Settled primary polyps start to deposit calcareous skeletons from one day following metamorphosis, which bud in extratentacular mode, starting from one to two weeks following settlement, a process that adds up to six additional polyps as a circlet around the primary polyp, all further forming the basal plate which is the initial colonial anchor to the substrate. Growth rates of new polyps over time are highly variable among young colonies (Frank et al. 1997). At some yet-unidentified stage, branches initiate by apical growth, usually just as a single apical ramified structure from each basal plate. New upgrowing and side-growing branches are then added by dichotomous fission at a branch tip (Rinkevich 2000, 2001, 2002; Rinkevich and Loya 1985a), developing in conformity with the basic architectural rules of this species, all together forming reiterated complexes (Epstein and Rinkevich 2001; Shaish et al. 2006, 2007; Shaish and Rinkevich 2009). The colony's growth exhibits allometric ratios within the newly developing dichotomous up-growing branches that differ significantly from those of older branches, decrease in growth rates of inward-growing lateral branches and changes in growth directionality of isogeneic branches that risk contiguity (Rinkevich and Loya 1985a). In addition to that, the lack of fusion between closely growing branches within a colony and the retreat growth occasionally recorded between closely growing allogeneic branches (Rinkevich and Loya 1985b) further emphasizes the within-colony genetic background for spatial configuration (Rinkevich 2001, 2002). The deduced genetic control (Rinkevich 2001, 2002; Shaish et al. 2006, 2007; Shaish and Rinkevich 2009), internal and external transport of signals (Kücken et al. 2011; Rinkevich and Loya 1985a) and external and internal nutrients (Rinkevich $1989,1991)$ may have substantial impacts on the pattern formation of S. pistillata colonies.

The growth of $S$. pistillata can be measured by several methodologies. Linear extension represents the increase in the length of a single branch or the diameter of a colony by units of distance (i.e. $\mathrm{mm}, \mathrm{cm}$ ). Aerial size represents the increase in surface area as viewed from above, in units of surface area $\left(\mathrm{mm}^{2}\right)$. Tissue surface area (including all branches) measurements can further be evaluated by wrapping all branches in aluminum foil (Marsh 1970) or by dipping the colony in wax (parafilm) and comparing the wax/aluminum foil weights with calibrated curves of mass increment vs. surface area (Stimson and Kinzie 1991), translating weighs to units of area $\left(\mathrm{mm}^{2}\right)$. The parameter of the ecological volume of a colony is the aerial size multiplied by the height and is 
measured by an increase of the whole space encompassed by the coral branches in $\mathrm{mm}^{3}$ (Shafir and Rinkevich 2010; Shafir et al. 2006b). Other size methods, such as 3D photography for measuring parameters of growth rates (surface areas, volumes, etc.), do not always give accurate results due to the high structural complexity of developing colonies.

S. pistillata is a fast-growing species as compared to massive and encrusting species and some other branching species. Branches can grow up to $5 \mathrm{~cm}$ per year, depending on the conditions and the initial fragment size (Dar and Mohamed 2017; Bockel and Rinkevich 2019; Hasan 2019; Liberman et al. 1995; Loya 1976; Shafir and Rinkevich 2010; Shafir et al. 2006b; Tamir et al. 2020), and small fragments can multiply their ecological volumes by 200 times within 8-12 months (Shafir and Rinkevich 2008). In old senescent colonies, calcification rates, as reproductive activities, decrease synchronically in all branches, and the whole colony as a single unit, new and old polyps alike, exhibits senescence concurrently, leading to accelerated degradation and colonial death within few months (Rinkevich and Loya 1986).

S. pistillata colonies that grow under improved water flows (primarily in mid-water floating nurseries) that assist the polyps in catching prey exhibit enhanced growth rates and advanced recovery from bleaching (in all parameters mentioned previously) (Bongiorni et al. 2003a; Nakamura et al. 2003; Shafir and Rinkevich 2010). In contrast to the high and fast growth rates characteristic to $S$. pistillata and although it is one of the most abundant species in the GOA/E (Shaked and Genin 2019; Shlesinger and Loya 2016), adult colonies and primarily recruits have high mortality rates (Doropoulos et al. 2015; Linden and Rinkevich 2011, 2017; Loya 1976; Shafir, Van Rijn, and Rinkevich 2006b; Shlesinger and Loya 2016; Tamir et al. 2020). Assuming 50-80\% settlement rates in the wild (Amar et al. 2007; Linden and Rinkevich 2011), only a small portion of recruits will develop into gravid colonies out of tens of millions and more of planulae released during any reproduction season. Under in-situ aqua-culture conditions, young colonies can reach a $40-80 \%$ survival rate if protected by cages and $10-30 \%$ if not protected (Linden and Rinkevich 2017; Shafir et al. 2006b), orders of magnitude above natural figures. Nevertheless, size structure demographic models for $S$. pistillata populations in various reefs were not constructed and are not yet available, in spite of their importance for conservation and management plans (Doropoulos et al. 2015).

\subsubsection{Metabolism}

In the past four decades, $S$. pistillata has been used as a model species in studies on carbon and nutrients assimilation and their acquisition, allocation and uptake by coral and by symbiotic algae. Since most coral reefs thrive in oligotrophic waters, it is essential to understand nutrient recycling by reef communities, as it may shed light on coral life histories and reef-resilient. S. pistillata colonies, as other coral species get carbon and nutrients through two main processes: via photosynthesis, provided by the symbiotic autotrophic algae (Muscatine et al. 1981), and by feeding on particular or dissolved sources of organic carbon (Houlbrèque and Ferrier-Pagès 2009). The symbiotic dinoflagellates cannot provide all the essential carbon and organic nitrogen needed for the coral, especially under low light regimens (Falkowski et al. 1984; Muscatine et al. 1984; Tremblay et al. 2014). Yet corals may modify their algal numbers and their activities. Studies on $S$. pistillata revealed that under high light regimes, respiration and calcification rates increased (Dubinsky and Jokiel 1994), while the symbiotic algae decreased in size and numbers, further showing high respiration and lower quantum yields (Dubinsky et al. 1984). With regard to nitrogen, another limiting nutrient source for the algae (Hoegh-Guldberg and Smith 1989a), increasing concentrations of nitrogen compounds such as ammonium, urea, amino acids, nitrite and nitrate lead to an increase in the nitrogen uptake by the holobiont (Dubinsky and Jokiel 1994; Grover et al. 2002, 2003, 2006, 2008; Houlbre'que and Ferrier-page 2009; Rahav et al. 1989). The fate and path of each nitrogen source, whether consumed via water or by feeding (praying of zooplankton), is mostly determined by light intensity and photosynthetic products (Dubinsky and Jokiel 1994; Houlbrèque and Ferrier-Pagès 2009). Assuming constant low nutrient concentration in the reef, under high light intensity regimes, most of the carbon goes to respiration and growth, including calcification by the host, while under low light, the zooxanthellae use the carbon and nutrients (Dubinsky and Jokiel 1994). Feeding on zooplankton or other pico- and nano-planktonic organisms increases nutrients uptake (including phosphate) that provides the nutrients needed for coral growth and reproduction (FerrierPagès et al. 2003; Houlbrèque et al. 2004; Houlbrèque et al. 2003) and enhances the numbers of zooxanthellae in the coral tissues (Dubinsky et al. 1990; Houlbrèque et al. 2003; Titlyanov et al. 2001; Titlyanov et al. 2000, 2001; Titlyanov et al. 2000). Studies on $S$. pistillata's symbiotic relationships further revealed the translocation of photosynthates between branches and along a branch within a colony and between genotypes (Rinkevich 1991; Rinkevich and Loya 1983b, 1983c, 1984a), and were used in quest on the "light enhanced calcification" enigma (Houlbrèque et al. 2003; Moya et al. 2006; Muscatine et al. 1984; Reynaud-Vaganay et al. 2001; Rinkevich and Loya 1984b). Despite all the previous studies on S. pistillata symbiotic relationships, there is a need for additional studies to reveal the more intimate interactions between the holobiont participants (Ferrier-Pagès et al. 2018; Hédouin et al. 2016; Metian et al. 2015).

\subsection{EMBRYOGENESIS}

As a hermaphroditic brooder species, S. pistillata fertilization and larval development take place within the body cavities of the polyps, thus making it challenging to study embryogenesis and larval development. Rinkevich and Loya (1979a) and then Ammar et al. (2012) observed that male and female gonads, situated on small stalks, start to develop at two and five months, respectively, before the onset of larval 

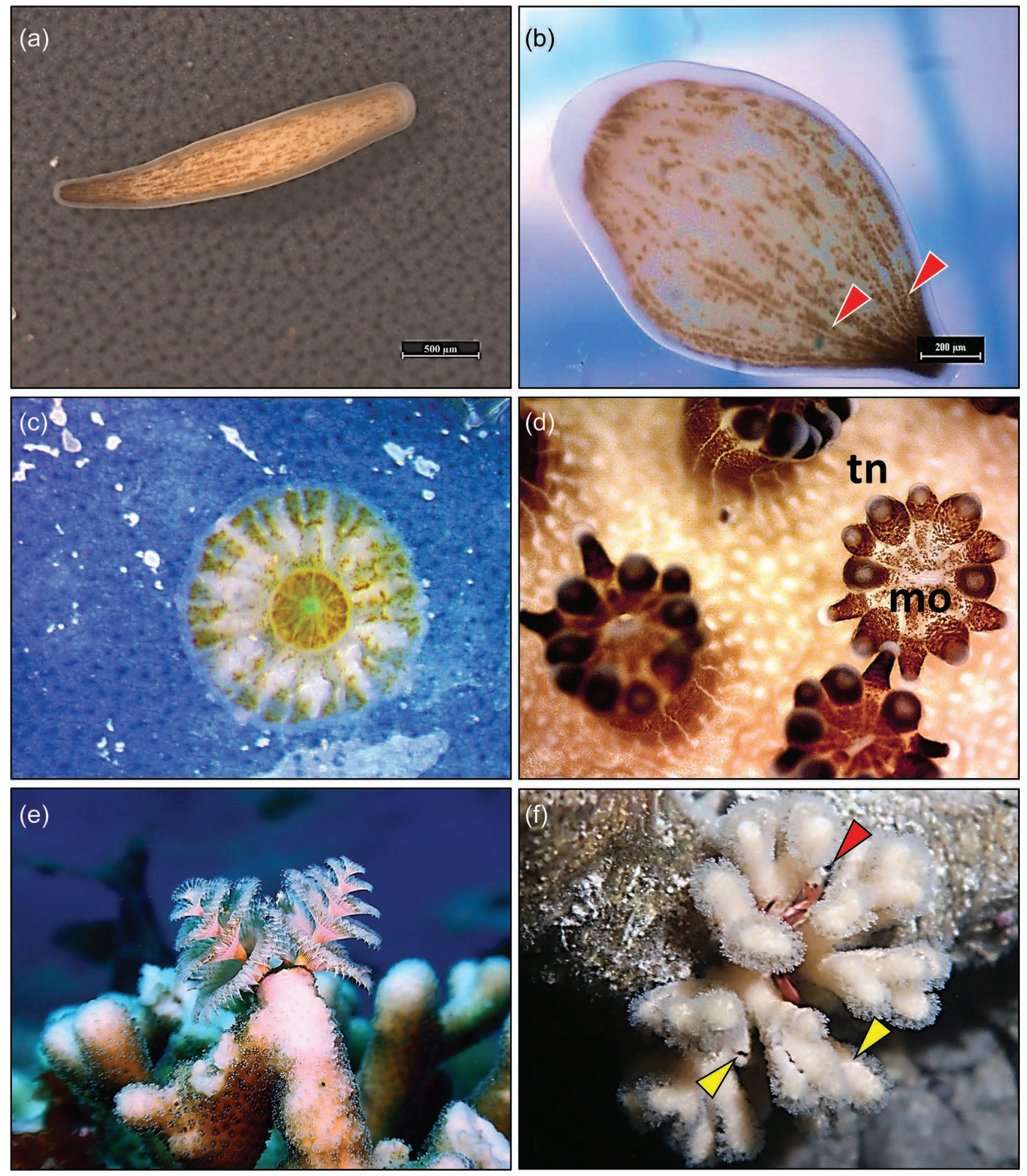

FIGURE 11.2 (a) Planula of Stylophora pistillata as a rod-like shape, the oral part facing to the left side of the picture. (b) Planula of S. pistillata as a ball-like shape. The planula is "enveloped" by secreted mucus, further revealing the pattern of symbiotic algae (brown dots) that also depict the mesenteries' tissues (ms). (c) A primary polyp, one day after settlement. (d) Extended polyps in S. pistillata, each with an open mouth (m) surrounded by 12 tentacles (tn), loaded with zooxanthellae, which give the coral its brown color. (e) The Christmas tree worm Spirobranchus giganteus (Polychaete) on top of an S. pistillata branch. (f) Trapezia cymodoce (Decapoda) "guarding" a juvenile $S$. pistillata colony (red arrowhead). The green arrowheads point to the coral gall crabs Hapalocarcinus marsupialis (Cryptochiridae) that modify the morphology of the branch. (Photographs [a-e] courtesy of D. Shefy; [f] courtesy of Y. Shmuel.) 
release (reproductive season), filling up the gastric cavities of the polyps during the peak of reproduction season. At the start, 4-16 oocytes per polyp develop; some are absorbed during the development in such a way that only a single mature egg at a specific time is left (Rinkevich and Loya 1979a). The migration of the egg nuclei to the periphery signals that the eggs are ready for fertilization (Rinkevich and Loya 1979a). Larval development is assumed to take 14 days, but the whole development process was not studied (Fan and Dai 2002; Rinkevich and Loya 1979b). Planulae develop in most polyps (except for the sexually sterile branch tips), and upon the release of the larva from a specific polyp, another oocyte becomes ready for fertilization. A mature planula has an organized ectodermal epithelium and a less organized gastrodermis loaded with zooxanthellae, separated by a thin mesoglea, and has six pairs of mesenteries (Figure 11.2a, b) (Atoda 1947a; Fan and Dai 2002; Rinkevich and Loya 1979a; Scucchia et al. 2020). Further, planulae of S. pistillata from the Red Sea (not observed in other planulae, including of $S$. pistillata from other places) show temporary extensions from the body wall, consisting of ectodermal-mesogleal material ("filaments") and extensions containing endodermal epithelium only ("nodules") that regularly appear and absorb (Rinkevich and Loya 1979a). The developing larvae are flexible in their morphologies, and, while globular upon release, they appear as pear-like, disk-like or rod-like structures (Figure 11.2a, b) (Atoda 1947a; Rinkevich and Loya 1979a). Planulae of S. pistillata that are released from shallow water gravid colonies are fluorescent (Grinblat et al. 2018; Rinkevich and Loya 1979a; Scucchia et al. 2020), with a lower expression of the green fluorescence protein (GFP) gene in planulae originating from $>30 \mathrm{~m}$ colonies (Scucchia et al. 2020). It has further been documented that planulae start to precipitate minerals in the form of small crystals that may assist in rapid calcification upon settlement (Akiva et al. 2018).

\subsection{GENOMIC DATA}

Advances, reduced costs of sequencing and improved technologies over the past decade enabled the recent sequencing and assembling of the S. pistillata genome (the full sequenced genome can be found at http://spis.reefgenomics. org/) (Banguera-Hinestroza et al. 2013; Voolstra et al. 2017). The sequenced genome enabled studies on evolutionary adaptation and origin of this species (Voolstra et al. 2017), algae-host relationships, gene expression analyses (Barott et al. 2015b; Gutner-Hoch et al. 2017; Karako-Lampert et al. 2014; Liew et al. 2014; Maor-Landaw and Levy 2016) and studies on epigenetics (Dimond and Roberts 2016; Liew et al. 2018). Results further revealed the genes involved in stressed (and not stressed) colonies as the molecular mechanisms for adaptation to global change impacts. S. pistillata mitochondrial DNA (mDNA) was used to investigate phylogenetic aspects, species delineation and the taxonomical status of this species (Chen et al. 2008; Flot et al. 2011; Keshavmurthy et al. 2013; Klueter and Andreakis 2013; Stefani et al. 2011), further elucidating that the origin of S. pistillata is from the west Indian ocean and that this species presents of up to six distinct morphs. Molecular markers such as ITS1, amplified fragment length polymorphism (AFLP) and allozymes were used to assess the genetic structure among different $S$. pistillata populations, within populations and coral recruits (Amar et al. 2008; Ayre and Hughes 2000; Douek et al. 2011; Takabayashi et al. 2003; Zvuloni et al. 2008) yet are too few to reveal clear genetic landscapes.

\subsection{FUNCTIONAL APPROACHES: TOOLS FOR MOLECULAR AND CELLULAR ANALYSES}

Despite the claim that $S$. pistillata is a "weedy species" (Loya 1976), the biological characteristics of this species, such as its fast growth rates, abundance and long reproductive season, made $S$. pistillata a model animal in a wide range of ecological settings and for functional approaches. It also helped that while $S$. pistillata colonies present several color morphs (Figure 11.1b, c) (Stambler and Shashar 2007), this diversity has no connection to either ecological feature studied (Rinkevich and Loya 1979b, 1985b).

\subsubsection{The Use of S. Pistillata as a Model Species in Studies on Climate Change AND ANTHROPOGENIC IMPACTS}

The decline of coral reef resilience and persistence due to anthropogenic impacts and global warming is of great concern for the future of reef ecosystems (Bindoff et al. 2019). $S$. pistillata has further served as a model species for analyzing a wide range of stressors on corals and symbionts, on various life history parameters and on coral adaption to changing environments. These studies further examined the holobiont (coral/algal) symbiotic relationships on the wholeorganism level (respiration, calcification rates, survival and photosynthesis), on the cellular level (organelles, lipids, proteins and stress-related proteins) and on a molecular level (DNA damage, gene expression and symbiont identity). In these studies, S. pistillata colonies are often used for elucidating coral responses to thermal stress (increasing of seawater temperatures), with consequences that are determined by the specific zooxanthellae species and the coral genotype subjected to specific stress conditions (Sampayo et al. 2008), further associated with alteration in the symbiont clades toward more physiologically suited algal populations (Fitt et al. 2009; Sampayo et al. 2016).

Ex-situ and in-situ experiments with S. pistillata revealed damages to the thylakoid membranes of the symbiotic algae when colonies are exposed to elevated temperatures and increased light intensities (Tchernov et al. 2004), also following other biological and physiological stresses, all expressed with induced photoinhibition and decreased photosynthesis (Bhagooli and Hidaka 2004; Cohen and Dubinsky 2015; Falkowski and Dubinsky 1981; Franklin et al. 2004; Hawkins et al. 2015; Hoegh-Guldberg and Smith 
1989b; Yakovleva et al. 2004), reduced algal density with time (Abramovitch-Gottlib et al. 2003; Biscéré et al. 2018; Cohen and Dubinsky 2015) and decreased protein concentration (Falkowski and Dubinsky 1981; Hoegh-Guldberg and Smith 1989b; Rosic et al. 2020). When evaluating the impacts on the host $S$. pistillata and its responses, studies documented that elevated temperatures increase coral respiration (Hall et al. 2018; Hoegh-Guldberg and Smith 1989b; Reynaud et al. 2003); enforced impacts on calcification rates (mixed results, increase or decrease; Abramovitch-Gottlib et al. 2003; Biscéré et al. 2018; Hall et al. 2018; Reynaud et al. 2003); decreased protein and lipid contents (Falkowski and Dubinsky 1981; Hall et al. 2018; Rosic et al. 2020); imposed fluctuations in ROS and antioxidant enzymes) such as superoxide dismutase [SOD], catalase [CAT], ascorbate peroxidase $[\mathrm{APX}]$, glutathione S-transferase [GST] and glutathione peroxidase [GPX]), primarily if light stress was co-involved (Hawkins et al. 2015; Saragosti et al. 2010; Yakovleva et al. 2004); and increased coral mortality rates (Dias et al. 2019). These physiological responses are further reflected in gene expression patterns, including the upregulation of key cellular processes associated with heat stress such as oxidative stress, energy metabolism, DNA repair and apoptosis (Maor-Landaw and Levy 2016). While it is a possibility that higher-latitude $S$. pistillata populations show a general improved tendency for adaptation to temperature changes (Pontasch et al. 2017), the suggestion that S. pistillata from the Red Sea specifically went through evolutionary adaptation to heat stress (Fine et al. 2013) made this species a model animal for experiments examining climate change impacts on corals (Bellworthy and Fine 2017; Bellworthy et al. 2019; Bellworthy et al. 2019; Hall et al. 2018; Grottoli et al. 2017; Krueger et al. 2017). Other studies examined the ecological consequences of global change, such as on allogeneic and xenogeneic interactions (Horwitz et al. 2017).

Following the results that $S$. pistillata colonies accumulate metal from seawater (Ali et al. 2011; Al-Sawalmih et al. 2017; Ferrier-Pagès et al. 2005), studies have further investigated $S$. pistillata holobiont responses to metal pollution and the combined effects with warming seas. High concentrations of copper have negative impacts on the holobiont, expressed as a decrease in photosynthesis efficiency, algal density, host respiration rate and host protein and increase in SOD activity, especially when combined with elevated temperature (Banc-Prandi and Fine 2019). Biscéré et al. (2018) further found that while manganese (Mn) enhances cellular chlorophyll concentration and photosynthesis efficiency and increases $S$. pistillata resistance to heat stress, and iron (Fe) positively affects the holobiont and symbionts (Biscéré et al. 2018; Shick et al. 2011), seawater enriched with Mn and iron decreases calcification and induces bleaching. Increased concentrations of Cobalt (Co) inflicted decreased growth rates under ambient $\mathrm{pH}$ conditions and in lower-pH water but had no impacts on photosynthesis under ambient $\mathrm{pH}$ conditions (Biscéré et al. 2015).

Numerous studies used $S$. pistillata as a model coral species to investigate the impacts of a wide range of pollutants on corals, such as oil pollution, sunscreen lotion detergents and eutrophication. Results revealed that some sunscreen ingredients might induce extensive necrosis in the coral's epidermis and gastrodermis layers (Downs et al. 2014), impair photosynthetic activity (Fel et al. 2019) and promote viral infection followed by bleaching (Danovaro et al. 2008). In-situ and ex-situ experiments showed that crude oil and its derivatives have a destructive effect on sexual reproduction in $S$. pistillata by reducing the number of female gonads per polyp (Rinkevich and Loya 1979c), by inducing the abortion of planulae (Epstein et al. 2000; Loya and Rinkevich 1979), by decreasing the settlement rate (Epstein et al. 2000), through DNA damage (Kteifan et al. 2017) and by intensifying coral and larval mortalities (Epstein et al. 2000). The same applies to detergents in seawater that impair basic $S$. pistillata biological features (Shafir et al. 2014) and anti-fouling compounds (Shafir et al. 2009). Studies also revealed that under various scenarios for nutrient-enriched environments, eutrophication even enhances S. pistillata performance, as colonies exhibited increased growth rates (Bongiorni et al. 2003a, 2003b), increases in host mitochondrial and protein concentrations (KramarskyWinter et al. 2009; Sawall et al. 2011), decreases in oxidation (Kramarsky-Winter et al. 2009) and increases in teste and egg numbers with a decrease in their size (Ammar et al. 2012; Bongiorni et al. 2003a). The healthy physiological status, in contrast to lab experiment results, suggests that the corals gain more energy through heterotrophy (increase in zooplankton) rather than autotrophy (Rinkevich 2015c).

Light has a significant role in marine invertebrates' biological clocks and is a cue in the regulation of circadian rhythms (zeitgeber) and physiological processes. Therefore, S. pistillata was further used as a model species for light pollution, following the observation that the coral reefs in the northern tip of the GOA/E, Red Sea, are heavily subjected to artificial light pollution at night (ALAN) (Aubrecht et al. 2008; Tamir et al. 2017). Shefy et al. (2018) postulated that changes in the length of the reproductive season in S. pistillata from Eilat might be the outcomes of increased ALAN in the last four decades. Further, reduced settlement rates were recorded in planulae exposed to ALAN as compared to regular light regimes, and a year upon settlement, the formerly impacted young colonies exhibited lower photosynthesis efficiency, albeit higher survival, growth and calcification rates (Tamir et al. 2020). Adult S. pistillata colonies as their symbionts showed increased oxidative damage in lipids and increased respiration rate and experienced loss of symbionts and enhanced photoinhibition at decreased photosynthetic rates (Levy et al. 2020).

\subsubsection{Larval Collection and Settlement}

As mentioned, S. pistillata is a brooding coral with a long reproduction season in some bio-geographical areas. By using this reproduction strategy, scientists can also use the planulae of $S$. pistillata as a model animal. In order to catch planulae easily, a planulae trap is used (Akiva et al. 2018; 


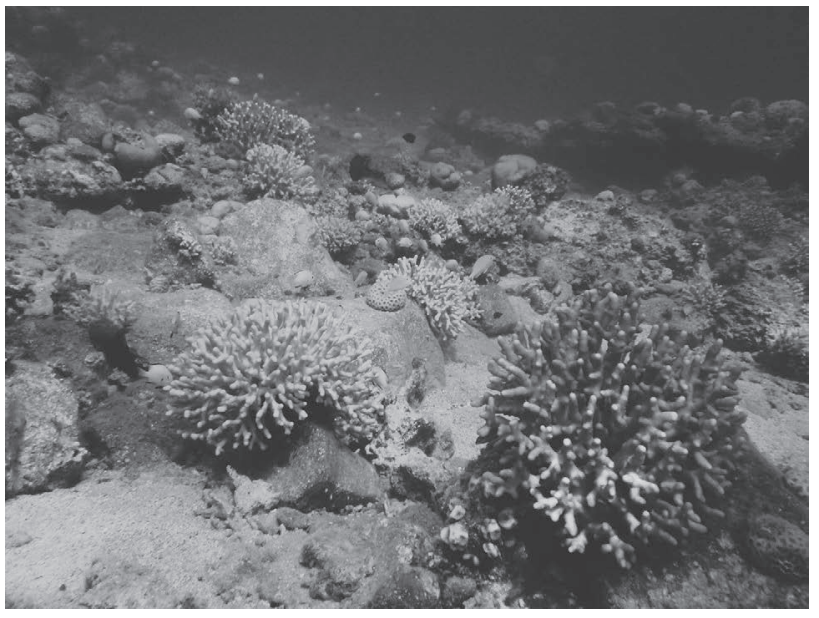

FIGURE 11.3 A shallow reef in Eilat, Gulf of Aqaba/Eilat dominated by colonies of S. pistillata. The future reefs ("reefs of tomorrow") will be dominated by a small number of species and lower diversity but may still keep their 3D structure and substrate complexity. (Photograph courtesy of D. Shefy.)

Amar et al. 2007, 2008; Douek et al. 2011; HoroszowskiFridman et al. 2020; Linden et al. 2018, 2019; Linden and Rinkevich 2011, 2017; Rinkevich and Loya 1979b, 1987; Scucchia et al. 2020; Shefy et al. 2018; Tamir et al. 2020; Zakai et al. 2006). This is a trap that is similar to a plankton trap but on a smaller scale, and its use is passive (no need to tow) (Amar et al. 2007; Rinkevich and Loya 1979b; Zakai et al. 2006). The planulae are released from the colony at night and have positive buoyancy in the first few hours after release. As a result, the trap should be placed slightly before sunset and picked up in the early morning or in the middle of the night. The released planulae are trapped in a jar that is located at the top of the traps. Because in some bio-geographical regions, $S$. pistillata does not reproduce according to the lunar phase, and the reproduction season is long, planulae can be collected with few limitations on dates. In contrast to in-situ collection with planulae traps, ex-situ collection of planulae does not require a trap. Nevertheless, ex-situ planulae collection results in a lower number of planulae per colony that do not represent the planulae yield in the field (Zakai et al. 2006). To the best of our knowledge, sexual reproduction of $S$. pistillata has never been documented in a closed-system aquarium. Large amounts of planulae during the majority of the year also enable the study of settlement or early life stages (Amar et al. 2007, 2008; Atoda 1947a; Baird and Morse 2004; Heyward and Negri 2010; Nishikawa et al. 2003; Putnam et al. 2008; Rinkevich and Loya 1979a; Tamir et al. 2020). As mentioned earlier, the planulae of $S$. pistillata are not very selective for substrate and may settle on smooth materials (like microscope slides) without the presence of red algae such as in other coral species (Atoda 1947b; Nishikawa et al. 2003; Putnam et al. 2008; Rinkevich and Loya 1979a). Planulae which settled on the water surface can be resettled (Frank et al. 1997). By using a fine small brush, one can gently move the floating primary polyps to the desired substrate.

\subsubsection{Establishing Allorecognition Assays}

This species is commonly used to elucidate the nature and dynamics of intraspecific interactions (between $S$. pistillata individuals) and interspecific interaction (between S. pistillata colonies and other species in the reef) and to elucidate "self" and "non-self" recognition. Studies clearly showed that a $S$. pistillata colony might distinguish between different neighbors and responds differentially to different allogeneic and xenogeneic challenges (Chadwick-Furman and Rinkevich 1994; Frank et al. 1997; Frank and Rinkevich 1994; Müller et al. 1984; Rinkevich 2004, 2012; Rinkevich and Loya 1985a 1985b). By detecting degraded tissues at contact areas between adjacent coral species in the field, Abelson and Loya (1999) and Rinkevich et al. (1993) defined linear and circular aggression hierarchies among coral species in the GOA/E where $S$. pistillata has emerged as one of the inferior partners in the hierarchies of interspecific interactions. Employing grafting assays, whether in-situ or ex-situ settings, gained control of the participants' identity in the interaction. Experiments with grafts were conducted by simple methodologies such as attaching allogeneic coral fragments by laundry clips. Conducting hundreds of allogenic assays, Rinkevich and Loya (1983a) and ChadwickFurman and Rinkevich (1994) further confirmed the control of genetic background on intra- and interspecific interactions in S. pistillata. While allografts (interaction between different $S$. pistillata genotypes) will have an array of different responses (Figure 11.1e), iso-grafts (within the same S. pistillata genotype) will fuse upon direct tissue contacts (Chadwick-Furman and Rinkevich 1994; Müller et al. 1984; Rinkevich and Loya 1983a), some of which are the outcome of the secretion of isomones-unknown chemical substances that are released into the water column (Rinkevich and Loya 1985a). In S. pistillata, adult genotypes do not fuse, yet, in the early life stages of the coral, fusion may occur in zero- to four-month-old colonies (Amar et al. 2008; Amar and Rinkevich 2010; Frank et al. 1997). Genetic relatedness was observed to affect the fusion rates between juveniles, where young colonies that shared at least one parent (kins) had higher fusion rates than non-siblings (Amar et al. 2008; Amar and Rinkevich 2010; Frank et al. 1997; Shefy, personal communication).

\subsubsection{Population Genetics}

Since kin relatedness level (coefficient of relationship) may influence genetic diversity, and larval connectivity may affect the intraspecific interactions within a population and consequently shape population fitness, it is necessary to understand the population genetics in and between different reefs. A comparison of microsatellites or other genetic markers of gravid colonies and planulae among different reefs may reveal connectivity and genetic flow processes and patterns. 
Elements of population genetic structures of $S$. pistillata populations were studied along the GBR, Okinawa and GOAlE, revealing a high contribution of sexual reproduction to the populations (Ayre and Hughes 2000; Takabayashi et al. 2003; Zvuloni et al. 2008). Yet significant differences in polymorphic allozyme loci diversity were recorded between populations in the same geographical region, implying low levels of connectivity but sufficient genetic diversity to maintain gene flow among reefs (Ayre and Hughes 2000). The low genetic flow among reefs is also related to the fast settlement rates of most released larvae, where the vast majority of the planulae metamorphose 24-48 hours upon release, a time scale that is varied between early and late phases of the reproduction season (Nishikawa et al. 2003; Amar et al. 2007; Rinkevich and Loya 1979a). Yet there are no detailed population genetics studies that employed highly polymorphic markers, reinforcing the need to develop additional efficient and inexpensive tools.

\subsubsection{Establishing S. pistillata as a Model Orgnism for ReEF Restoration}

The accelerating climate change and its effects on the coral reefs and the recognition that passive management measures (such as the declaration of marine protected areas) are not enough to cope with climate change (Bindoff et al. 2019; Rinkevich 2008) have raised the need for active reef restoration (Rinkevich 1995, 2000, 2005, 2014, 2015a, 2015b). Much of the work published on active reef restoration has emerged as of the end of the 1990s and has considered colonies of S. pistillata for the research and development of new reef restoration methods and approaches. Most of the colonies that were maintained in the first constructed floating nurseries in the $\mathrm{GOA} / \mathrm{E}$, including microcolonies and 2-5-cm-long fragments of S. pistillata, exhibited fast growth rates and high survival rates (Epstein et al. 2001; Linden and Rinkevich 2017; Linden et al. 2018; Rinkevich 2000; Shafir and Rinkevich 2010; Shafir et al. 2001, 2003, 2006b). The same applied to transplantation acts performed in Eilat and other Indo-Pacific sites (Golomb et al. 2020; Horoszowski-Fridman et al. 2015; Horoszowski-Fridman et al. 2020). S. pistillata was further used in various ecological engineering approaches. To achieve higher genetic diversity, several studies (Linden and Rinkevich 2011, 2017; Linden et al. 2019) worked on S. pistillata planulae as source material for reef restoration. They collected planulae and reared them in two ways: (1) in situ, using a special designated settlement box that allowed the planulae to settle in situ on artificial substrates (Linden et al. 2019), and (2) ex situ, in outdoor aquarium systems (Linden and Rinkevich 2011), and then developing spat were moved and farmed in floating nurseries (Linden and Rinkevich 2011, 2017). Several versions of methodologies adopted various colony orientations (vertical or horizontal), protection methods against predation (in or out of cages) and locations in the nursery. These developing methods yielded high survival rates, involved minimal maintenance in the developing spat and successfully enhanced genetic diversity. By harnessing the ability of isogeneic fragments to fuse, Rachmilovitz and Rinkevich (2017) formed, within six to seven months, flat $S$. pistillata tissue plates from glued fragments on plastic tiles in the purpose of creating two-dimensional corals units (that can cover degraded substrates). Furthermore, it was shown that nursery-farmed coral colonies that had been transplanted into a degraded reef at Eilat (Dekel Beach) revealed higher fecundity (Horoszowski-Fridman et al. 2020) than native colonies, and when transplanted with other species, they attracted planulae settlement (Golomb et al. 2020). Harnessing chimerism, the fusion between different genotypes (possible during only at early life stages), has also been proposed as an active reef restoration tool to mitigate climate change impacts (Rinkevich 2019b). Chimerism can benefit the coral entity by causing increased sizes, high genotypic diversity and and enhanced phenotipic plasticity.

\subsection{CHALLENGING QUESTIONS BOTH IN ACADEMIC AND APPLIED RESEARCH}

Out of the many challenging topics associated with the use of $S$. pistillata as a model system for coral biology, three challenging topics are outlined in the following as being of primary importance in the biology of this species.

\subsubsection{BIOMINERALIZATION}

The mechanisms controlling coral calcification at the molecular, cellular and entire tissue levels are still not fully understood. Over the past few decades, S. pistillata has been used as one of the model organisms for studying calcification in corals. Although numerous papers has been published, the calcification process remains an enigmatic biological phenomenon, as its nature, including physiochemically controlled mechanisms or its biologically mediated machinery, have not yet been resolved (Allemand et al. 2011). Within the last three decades, numerous studies have engaged with various aspects of coral calcification, while many of them have used $S$. pistillata as the model organism for corals (Allemand et al. 2004; Drake et al. 2019; Falini et al. 2015). As mentioned earlier, the calcifying tissue is the calicoblastic layer, an epithelium attached to the skeleton with desmocytes (Muscatine et al. 1997; Raz-Bahat et al. 2006; Tambutté et al. 2007), thus found in direct contact with the skeleton surface (Tambutté et al. 2007). The calicoblastic ectoderm produces the extracellular matrix (ECM) proteins that are secreted to the calcifying medium and remain preserved in the skeleton organic matrix (Allemand et al. 2011). Coral skeletal aragonite is produced within the ECM, which is secreted into semi-enclosed extracellular compartments and composed of a few nano-micrometers-thick matrix elements (Mass et al. 2017a; Sevilgen et al. 2019; Tambutté et al. 2007). The cells in the calicoblastic layer are connected through tight junctions that control the diffusion of molecules to the ECM (Barott et al. 2015a; Raz-Bahat et al. 2006; Tambutté et al. 1996, 2007, 2012; Zoccola et al. 1999, 2004). 
This paracellular pathway depends on the charge and size of the molecules (Tambutté et al. 2012). Furthermore, a second path of calcium ions to the center of calcification through an intracellular pathway was proposed. By using in vitro primary cell cultures of $S$. pistillata and employing antibodies against ion transporters, several studies (Barott et al. 2015a; Mass et al. 2012, 2017a) showed that calcium is concentrated in intracellular pockets and is exported to the site of calcification via vesicles (Ganot et al. 2020). Dissolved inorganic carbon (DIC) can diffuse from the coral tissue to the ECM (Furla et al. 2000) or, alternatively, be transported via bicarbonate transporters from the calicoblastic cells' cytosol to the ECM (Zoccola et al. 2015). The transport of proteins and minerals to the ECM is influenced and mediated by environmental parameters such as temperature, $\mathrm{pH}$, calcium saturation levels, pollutants and enzymes (Al-Sawalmih 2016; Allemand et al. 2004; Furla et al. 2000; Gattuso et al. 1998; Gutner-Hoch et al. 2017; Malik et al. 2020; Puverel et al. 2005; Zoccola et al. 1999, 2004, 2015). It is suggested that high amounts of acidic amino acids and glycine in the ECM (Puverel et al. 2005) allow the control of its chemical composition by increasing $\mathrm{pH}$ and DIC concentration above the surrounding water and enable the formation of aragonite (Drake et al. 2019; Venn et al. 2011). The skeletal organic matrix within the skeletal framework contains at least 60 proteins and glycosylated derivatives which remain entrapped within the crystalline units (Allemand et al. 2011; Drake et al. 2013; Mass et al. 2014; Peled et al. 2020; Puverel et al. 2007). The calicoblastic tissue secretes amorphous nano-calcium carbonate particles in the created microenvironments enriched in organic material aggregates that then crystallize to create ordered aragonitic structures (Mass et al. 2012, 2017b; Von Euw et al. 2017). S. pistillata colonies grow their skeletons from the centers of calcification areas of spherulitic shapes (radial distributions of acicular crystals), forming bundles of aragonite crystals (Sun et al. 2017, 2020).

\subsubsection{TAXONOMY}

S. pistillata is considered a model organism in research and has been the focus of coral research over the past four decades. This species is widely distributed in the Indo-Pacific region and represented by numerous morphological variations (morphotypes) associated with different reef habitats, geographical regions and reef depth zones (Figures 11.1b, $\mathrm{c}, \mathrm{d}, 11.3)$. Thus, for comparative studies, it is imperative to ensure its correct taxonomy and species delineation. Using molecular markers (mitochondrial and nuclear genes), aided by comparisons of morphological characteristics, enabled scientists to point toward the west Pacific and not the coral triangle, like for other corals, as the origin of $S$. pistillata (Flot et al. 2011; Stefani et al. 2011). Keshavmurthy et al. (2013) further revealed the presence of cryptic divergence and four distinct evolutionary lineages (clades) within S. pistillata across its distribution range: clade 1 is distributed in the Pacific Ocean (Klueter and Andreakis 2013), clade 2 is distributed over the Indian Ocean and clade 3 is found in the west Indian Ocean. The distribution of the fourth clade overlaps with clades 2 and 3, but this clade inhabits the Red Sea as well (Keshavmurthy et al. 2013). In contrast, Arrigoni et al. (2016) postulated that the different species of the genus Stylophora found in the Red Sea are actually ecomorphs of a single phenotypically plastic species that belong to a single molecular lineage. Further analyses are thus needed to evaluate the taxonomic status of S. pistillata and whether other species of Stylophora represent valid endemic species arising from speciation or locally emerged ecomorphs of $S$. pistillata that had been adapted to different environmental conditions (depth, temperature, etc.).

\subsubsection{AGING}

How long can a colony of $S$. pistillata live? Are colonies that Jacques Cousteau saw still alive? Some of the coral species attain considerable ages ( $>400$ years), but others have a shorter life span (reviewed in Bythell et al. 2018). The life span of $S$. pistillata was never followed in detail, but studies assumed it to be in the range of 20-30 years (Rinkevich, personal communication). Before natural death, a colony exhibits a decrease in the rate of reproduction, tissue degradation and a decrease in growth (Rinkevich and Loya 1986). Aging in such colonial species is of great interest, and telomeres can be used in the research as molecular markers of aging due to the common loss of telomeres repeating in other aging multicellular organisms, including humans. Additionally, coral stem cells, which can be used as another marker for aging, are not yet known in S. pistillata, nor in other coral species. Decreased regeneration abilities in some colonies could also be related to stem cell aging (Y. Rinkevich et al. 2009). Hence, S. pistillata may be used as a model species for aging and stem cell biology research of corals in general.

\subsubsection{Interactions With Associated Species That Colonize Harbors}

S. pistillata is an ecologically important key species, considered an r-strategist (Loya 1976) and an ecological engineering species (Rinkevich 2020) that harbors on branches, between branches and within the skeleton a wide range of fish species and species of large invertebrates, including cryptic, boring and encrusting organisms such as sponges, bivalves, polychaetes, crabs and others (Figure 11.2e, f) (Barneah et al. 2007; Belmaker et al. 2007; Berenshtein et al. 2015; El-Damhougy et al. 2018; Mbije et al. 2019; Garcia-Herrera et al. 2017; Goldshmid et al. 2004; Kotb and Hartnoll 2002; Kuwamura et al. 1994; Limviriyakul et al. 2016; Mohammed and Yassien 2013; Mokady et al. 1991, 1993, 1994; Pratchett 2001; Rinkevich et al. 1991; Shafir et al. 2008). Some of these organisms are commensals; others are corallivores, passing organisms or symbionts. The nature of such interactions is not always explicit. Garcia-Herrera et al. (2017) found that Dascyllus marginatus fish that are fanning their fins keep 
oxygen levels high during the night hours in the inner spaces of the colony between branches, where the photosynthetic oxygen levels are decreased (Shashar et al. 1993). Trapezia cymodoce, a xanthid crab which lives between $S$. pistillata's colony branches, grazes on the coral tissue (Rinkevich et al. 1991), yet colonies harboring this "parasitic" crab demonstrated higher survival rates (Glynn 1983), partly due to their aggressive behavior toward predators (Pratchett 2001). Some of the species live exclusively on/in S. pistillata colonies, including the gobiid fish Paragobiodon echinocephalus (Belmaker et al. 2007; Kuwamura et al. 1994) and the boring bivalve Lithophaga lessepsiana (Mokady et al. 1994). While very little is known about such biological associations, boring organisms such as bivalves and crustaceans can modify the colony morphology (Abelson et al. 1991). These associations become a challenging question, further highlighted by reef restoration acts that consider the whole reef communities and not solely the coral transplants.

\section{BIBLIOGRAPHY}

Abelson, A., B. Galil, and Y. Loya. 1991. "Skeletal modifications in stony corals caused by indwelling crabs: Hydrodynamical advantages for crab feeding." Symbiosis 10: 233-248.

Abelson, A., and Y. Loya. 1999. "Interspecific aggression among stony corals in Eilat, Red Sea: A hierarchy of aggression ability and related parameters." Bulletin of Marine Science 65 (3): 851-860.

Abramovitch-Gottlib, L., D. Katoshevski, and R. Vago. 2003. "Responses of Stylophora pistillata and Millepora dichotoma to seawater temperature elevation." Bulletin of Marine Science 73 (3): 745-755.

Akiva, A., M. Neder, K. Kahil, R. Gavriel, I. Pinkas, G. Goobes, and T. Mass. 2018. "Minerals in the pre-settled coral Stylophora pistillata crystallize via protein and ion changes." Nature Communications 9 (1). doi:10.1038/s41467-018-04285-7.

Al-Sawalmih, A. 2016. "Calcium composition and microstructure of coral Stylophora pistillata under phosphate pollution stress in the Gulf of Aqaba." Natural Science 8 (3): 89-95. doi:10.4236/ns.2016.83012.

Al-Sawalmih, A., F.A. Al-Horani, and S. Al-Rousan. 2017. "Elemental analysis of the coral Stylophora pistillata incubated along the Jordanian coast of the Gulf of Aqaba." Fresenius Environmental Bulletin 26 (4): 3029-3036.

Al-Sofyani, A.A. 1991. "Physiology and ecology of Stylophora pistillata and Echinopora gemmacea from the Red Sea." University of Glasgow, United Kindom.

Ali, A. hamid A.M., M.A. Hamed, and H.A. El-Azim. 2011. "Heavy metals distribution in the coral reef ecosystems of the Northern Red Sea." Helgoland Marine Research 65 (1): 67-80. doi:10.1007/s10152-010-0202-7.

Allemand, D., C. Ferrier-pagès, P. Furla, F. Houlbrèque, S. Puverel, S. Reynaud, É. Tambutté, S. Tambutté, and D. Zoccola. 2004. "Biomineralisation in reef-building corals: From molecular mechanisms to environmental control." General Palaeontology (Palaeobiochemistry) Biomineralisation 3: 453-467. doi:10.1016/j.crpv.2004.07.011.

Allemand, D., É. Tambutté, D. Zoccola, and S. Tambutté. 2011. "Coral calcification, cells to reefs." In Coral Reefs: An Ecosystem in Transition, eds. Dubinsky, Z. and Stambler, N., 119-150. Dordrecht: Springer Netherlands. doi:10.1007/978-94-007-0114-4_9.
Amar, K.O., N. Chadwick, and B. Rinkevich. 2007. "Coral planulae as dispersion vehicles: Biological properties of larvae released early and late in the season." Marine Ecology Progress Series 350 (November): 71-78. doi:10.3354/ meps07125.

Amar, K.O., N.E. Chadwick, and B. Rinkevich. 2008. "Coral kin aggregations exhibit mixed allogeneic reactions and enhanced fitness during early ontogeny." BMC Evolutionary Biology 8 (1): 126. doi:10.1186/1471-2148-8-126.

Amar, K.O., J. Douek, C. Rabinowitz, and B. Rinkevich. 2008. "Employing of the amplified fragment length polymorphism (AFLP) methodology as an efficient population genetic tool for symbiotic cnidarians." Marine Biotechnology 10 (4): 350-357. doi:10.1007/s10126-007-9069-2.

Amar, K.O., and B. Rinkevich. 2007. "A floating mid-water coral nursery as larval dispersion hub: Testing an idea." Marine Biology 151: 713-718. doi:10.1007/s00227-006-0512-0.

Amar, K.O., and B. Rinkevich. 2010. "Mounting of erratic histoincompatible responses in hermatypic corals: A multi-year interval comparison." Journal of Experimental Biology 213 (4): 535-540.

Ammar, M.S.A., A.H. Obuid-Allah, and M.A.M. Al-Hammady. 2012. "Patterns of fertility in the two Red Sea corals Stylophora pistillata and Acropora humilis." Nusantara Bioscience 4 (2): 62-75. doi:10.13057/nusbiosci/n040204.

Arrigoni, R., F. Benzoni, T.I. Terraneo, A. Caragnano, and M.L. Berumen. 2016. "Recent origin and semi-permeable species boundaries in the scleractinian coral genus Stylophora from the Red Sea." Scientific Reports 6 (January): 1-13. doi:10.1038/srep34612.

Atoda, K. 1947a. "The larva and postlarval development of some reef-building corals. II. Stylophora pistillata (Esper)." Science Reports of the Tohoku Imperial University, 4th Series (Biology) 18: 48-64.

Atoda, K. 1947b. "The larva and postlarval development of some reef-building corals. I. Pocillopora damicornis cespitosa (Dana)." Science Reports of the Tohoku Imperial University, 4th Series (Biology) 18: 24-47.

Atoda, K. 1951. "The larva and postlarval development of some reef-building corals. V. (Seritopora hystrix) Dana." Science Reports of the Tohoku University 4th Ser. (Biology) 19 (1): 33-39.

Aubrecht, C., C.D. Elvidge, T. Longcore, C. Rich, J. Safran, A.E. Strong, M. Eakin, et al. 2008. "A global inventory of coral reef stressors based on satellite observed nighttime lights." Geocarto International 23 (December 2015): 467-479. doi:10.1080/10106040802185940.

Ayre, D.J., and T.P. Hughes. 2000. "Genotypic diversity and gene flow in brooding and spawning corals along the Great Barrier Reef, Australia." Evolution 54 (5): 1590-1605. doi:10.1554/0014-3820(2000)054[1590:GDAGFI]2.0.CO;2.

Baird, A.H., and R.C. Babcock. 2000. "Morphological differences among three species of newly settled pocilloporid coral recruits." Coral Reefs 19 (2): 179-183. doi:10.1007/ PL00006955.

Baird, A.H., V.R. Cumbo, S. Gudge, S.A. Keith, J.A. Maynard, C.H. Tan, and E.S. Woolsey. 2015. "Coral reproduction on the world's southernmost reef at Lord Howe Island, Australia." Aquatic Biology 23 (3): 275-284. doi:10.3354/ab00627.

Baird, A.H., and A.N.C. Morse. 2004. "Induction of metamorphosis in larvae of the brooding corals Acropora palifera and Stylophora pistillata." Marine and Freshwater Research 55 (5): 469-472. doi:10.1071/MF03121.

Banc-Prandi, G., and M. Fine. 2019. "Copper enrichment reduces thermal tolerance of the highly resistant Red Sea 
coral Stylophora pistillata." Coral Reefs 38 (2): 285-296. doi:10.1007/s00338-019-01774-z.

Banguera-Hinestroza, E., P. Saenz-Agudelo, T. Bayer, M.L. Berumen, and C.R. Voolstra. 2013. "Characterization of new microsatellite loci for population genetic studies in the smooth cauliflower coral (Stylophora sp.)." Conservation Genetics Resources 5 (2): 561-563. doi:10.1007/s12686-012-9852-x.

Barneah, O., I. Brickner, M. Hooge, V.M. Weis, T.C. LaJeunesse, and Y. Benayahu. 2007. "Three party symbiosis: Acoelomorph worms, corals and unicellular algal symbionts in Eilat (Red Sea)." Marine Biology 151 (4): 1215-1223. doi:10.1007/ s00227-006-0563-2.

Barott, K.L., S.O. Perez, L.B. Linsmayer, and M. Tresguerres. 2015a. "Differential localization of ion transporters suggests distinct cellular mechanisms for calcification and photosynthesis between two coral species." American Journal of Physiology: Regulatory Integrative and Comparative Physiology 309 (3): R235-R246. doi:10.1152/ajpregu.00052.2015.

Barott, K.L., A.A. Venn, S.O. Perez, S. Tambutteeé, M. Tresguerres, and G.N. Somero. 2015b. "Coral host cells acidify symbiotic algal microenvironment to promote photosynthesis." Proceedings of the National Academy of Sciences of the United States of America 112 (2): 607-612. doi:10.1073/ pnas. 1413483112.

Bellworthy, J., and M. Fine. 2017. "Beyond peak summer temperatures, branching corals in the Gulf of Aqaba are resilient to thermal stress but sensitive to high light." Coral Reefs 36 (4). Springer Berlin Heidelberg: 1071-1082. doi:10.1007/ s00338-017-1598-1.

Bellworthy, J., M. Menoud, T. Krueger, A. Meibom, and M. Fine. 2019. "Developmental carryover effects of ocean warming and acidification in corals from a potential climate refugium, the Gulf of Aqaba." Journal of Experimental Biology 222 (1). doi:10.1242/jeb.186940.

Bellworthy, J., J.E. Spangenberg, and M. Fine. 2019. "Feeding increases the number of offspring but decreases parental investment of Red Sea coral Stylophora pistillata." Ecology and Evolution 9 (21): 12245-12258. doi:10.1002/ece3.5712.

Belmaker, J., O. Polak, N. Shashar, and Y. Ziv. 2007. "Geographic divergence in the relationship between Paragobiodon echinocephalus and its obligate coral host." Journal of Fish Biology 71 (5): 1555-1561. doi:10.1111/j.1095-8649.2007.01619.x.

Berenshtein, I., Y. Reuben, and A. Genin. 2015. "Effect of oxygen on coral fanning by mutualistic fish." Marine Ecology 36 (4): 1171-1175. doi:10.1111/maec.12218.

Bhagooli, R., and M. Hidaka. 2004. "Photoinhibition, bleaching susceptibility and mortality in two scleractinian corals, Platygyra ryukyuensis and Stylophora pistillata, in response to thermal and light stresses." Comparative Biochemistry and Physiology: A Molecular and Integrative Physiology 137 (3): 547-555. doi:10.1016/j. cbpb.2003.11.008.

Bindoff, N.L., W.W.L. Cheung, J.G. Kairo, J. Arístegui, V.A. Guinder, R. Hallberg, N. Hilmi, et al. 2019. Changing Ocean, Marine Ecosystems, and Dependent Communities. IPCC Special Report on the Ocean and Cryosphere in a Changing Climate [H.-O. Pörtner, D.C. Roberts, V. Masson-Delmotte, P. Zhai, M. Tignor, E. Poloczanska, K. Mintenbeck, A. Alegría, M. Nicolai, A. Okem, J. Petzold, B. Rama, N.M. Weyer (Eds.)]. www.ipcc.ch/srocc/download-report/.

Biscéré, T., C. Ferrier-Pagès, A. Gilbert, T. Pichler, and F. Houlbrèque. 2018. "Evidence for mitigation of coral bleaching by manganese." Scientific Reports 8 (1): 1-10. doi:10.1038/s41598-018-34994-4.
Biscéré, T., R. Rodolfo-Metalpa, A. Lorrain, L. Chauvaud, J. Thébault, J. Clavier, and F. Houlbrèque. 2015. "Responses of two scleractinian corals to cobalt pollution and ocean acidification." PLoS One 10 (4): 1-18. doi:10.1371/journal. pone. 0122898 .

Bockel, T., and B. Rinkevich. 2019. "Rapid recruitment of symbiotic algae into developing Scleractinian coral tissues." Journal of Marine Science and Engineering 7 (306). doi:10.3390/jmse7090306.

Bongiorni, L., S. Shafir, D. Angel, and B. Rinkevich. 2003a. "Survival, growth and gonad development of two hermatypic corals subjected to in situ fish-farm nutrient enrichment." Marine Ecology Progress Series 253 (2001): 137-144. doi:10.3354/meps 253137.

Bongiorni, L., S. Shafir, and B. Rinkevich. 2003b. "Effects of particulate matter released by a fish farm (Eilat, Red Sea) on survival and growth of Stylophora pistillata coral nubbins." Marine Pollution Bulletin 46 (9): 1120-1124. doi:10.1016/ S0025-326X(03)00240-6.

Byler, K.A., M. Carmi-Veal, M. Fine, and T.L. Goulet. 2013. "Multiple symbiont acquisition strategies as an adaptive mechanism in the coral Stylophora pistillata." PLoS One 8 (3): 1-7. doi:10.1371/journal.pone.0059596.

Bythell, J.C., B.E. Brown, and T.B.L. Kirkwood. 2018. "Do reef corals age?" Biological Reviews 93 (2): 1192-1202. doi:10.1111/brv.12391.

Chadwick-Furman, N., and B. Rinkevich. 1994. "A complex allorecognition system in a reef-building coral: Delayed responses, reversals and nontransitive hierarchies." Coral Reefs 13 (1): 57-63. doi:10.1007/BF00426436.

Chen, C., C.Y. Chiou, C.F. Dai, and C.A. Chen. 2008. "Unique mitogenomic features in the scleractinian family pocilloporidae (Scleractinia: Astrocoeniina)." Marine Biotechnology 10 (5): 538-553. doi:10.1007/s10126-008-9093-x.

Cohen, I., and Z. Dubinsky. 2015. "Long term photoacclimation responses of the coral Stylophora pistillata to reciprocal deep to shallow transplantation: Photosynthesis and calcification." Frontiers in Marine Science 2 (June): 1-13. doi:10.3389/ fmars.2015.00045.

Dai, C.F., K. Soong, and T.Y. Fan. 1992. "Sexual reproduction of corals in northern and southern Taiwan." 7th Int'l. Coral Reef Symp., 1: 448-455.

Danovaro, R., L. Bongiorni, C. Corinaldesi, D. Giovannelli, E. Damiani, P. Astolfi, L. Greci, and A. Pusceddu. 2008. "Sunscreens cause coral bleaching by promoting viral infections." Environmental Health Perspectives 116 (4): 441-447. doi:10.1289/ehp.10966.

Dar, M.A., and T.A.A. Mohamed. 2017. "Coral growth and skeletal density relationships in some branching corals of the Red Sea, Egypt." Journal of Environment and Earth Science 7 (11): 66-79.

Dias, M., A. Ferreira, R. Gouveia, C. Madeira, N. Jogee, H. Cabral, M. Diniz, and C. Vinagre. 2019. "Long-term exposure to increasing temperatures on scleractinian coral fragments reveals oxidative stress." Marine Environmental Research 150 (January): 104758. doi:10.1016/j.marenvres.2019.104758.

Dimond, J.L., and S.B. Roberts. 2016. "Germline DNA methylation in reef corals: Patterns and potential roles in response to environmental change." Molecular Ecology 25 (8): 18951904. doi:10.1111/mec.13414.

Doropoulos, C., S. Ward, G. Roff, M. González-Rivero, and P.J. Mumby. 2015. "Linking demographic processes of juvenile corals to benthic recovery trajectories in two common reef habitats." PLoS One 10 (5): 1-23. doi:10.1371/journal. pone. 0128535 . 
Douek, J., K.O. Amar, and B. Rinkevich. 2011. "Maternal-larval population genetic traits in Stylophora pistillata, a hermaphroditic brooding coral species." Genetica 139 (11-12): 15311542. doi:10.1007/s10709-012-9653-x.

Downs, C.A., E. Kramarsky-Winter, J.E. Fauth, R. Segal, O. Bronstein, R. Jeger, Y. Lichtenfeld, et al. 2014. "Toxicological effects of the sunscreen UV filter, benzophenone-2, on planulae and in vitro cells of the coral, Stylophora pistillata." Ecotoxicology 23 (2): 175-191. doi:10.1007/s10646-013-1161-y.

Drake, J.L., T. Mass, L. Haramaty, E. Zelzion, D. Bhattacharya, and P.G. Falkowski. 2013. "Proteomic analysis of skeletal organic matrix from the stony coral Stylophora pistillata." Proceedings of the National Academy of Sciences 110 (10): 3788-3793. doi:10.1073/pnas.1304972110.

Drake, J.L., T. Mass, J. Stolarski, S. Von Euw, B. van de Schootbrugge, and P.G. Falkowski. 2019. "How corals made rocks through the ages." Global Change Biology 26 (1): 31-53. doi:10.1111/gcb.14912.

Dubinsky, Z., P.G. Falkowski, J.W. Porter, and L. Muscatine. 1984. "Absorption and utilization of radiant energy by light and shade adapted colonies of the hermatypic coral Stylophora pistillata." Proceeding of the Royal Society of London 214 (1227): 203-214. https://doi.org/10.1098/rspb.1984.0059.

Dubinsky, Z., and P.L. Jokiel. 1994. "Ratio of energy and nutrient fluxes regulates symbiosis between zooxanthelae and corals." Pacific Science 48 (3): 313-324.

Dubinsky, Z., N. Stambler, M. Ben-Zion, L.R. McCloskey, L. Muscatine, and P.G. Falkowski. 1990. "The effect of external nutrient resources on the optical properties and photosynthetic efficiency of Stylophora pistillata." Proc. R. Soc. Lond. B 239: 231-246. doi:10.1098/rspb.1990.0015.

Edwards, A., and H. Emberton. 1980. "Crustacea associated with the scleractinian coral,Stylophorapistillata(Esper), in the Sudanese Red Sea." Journal of Experimental Marine Biology and Ecology 42: 225-240. doi:10.1016/0022-0981(80)90178-1.

El-Damhougy, K.A., E.-S.S.E. Salem, M.M.A. Fouda, and M.A.M.M. Al-Hammady. 2018. "The growth and reproductive biology of the coral gall crab, Hapalocarcinus marsupialis Stimpson, 1859 (Crustacea: Cryptochiridae) from Gulf of Aqaba, Red Sea, Egypt." The Journal of Basic and Applied Zoology 79 (1). The Journal of Basic and Applied Zoology. doi:10.1186/s41936-017-0010-6.

Epstein, N., R.P.M. Bak, and B. Rinkevich. 2000. “Toxicity of third generation dispersants and dispersed Egyptian crude oil on Red Sea coral larvae." Marine Pollution Bulletin 40 (6): 497 503. doi:10.1016/S0025-326X(99)00232-5.

Epstein, N., R.P.M. Bak, and B. Rinkevich. 2001. "Strategies for gardening denuded coral reef areas: The spplicability of using different types of coral material for reef restoration." Restoration Ecology 9 (4): 432-442.

Epstein, N., and B. Rinkevich. 2001. "From isolated ramets to coral colonies: The significance of colony pattern formation in reef restoration practices." Basic and Applied Ecology 2 (3): 219 222. doi:10.1078/1439-1791-00045.

Epstein, N., M.J.A. Vermeij, R.P.M. Bak, and B. Rinkevich. 2005. "Alleviating impacts of anthropogenic activities by traditional conservation measures: Can a small reef reserve be sustainedly managed?" Biological Conservation 121 (2): 243-255. doi:10.1016/j.biocon.2004.05.001.

Esper, E.J.C. 1797. Fortsetzungen Der Pflanzenthiere in Abbildugen Nach Der Natur Mit Farben Erleuchtet Nebst Beschreibungen. Vol. 1. In der Raspeschen Buchhandlung.

Fadlallah, Y.H., and R.T. Lindo. 1988. "Contrasting cycles of reproduction in Stylophora pistillata from the Red Sea and the
Arabian Gulf, with emphasis on temperature." Proceedings of the 6th International Coral Reef Symposium 3: 225-230.

Falini, G., S. Fermani, and S. Goffredo. 2015. "Coral biomineralization: A focus on intra-skeletal organic matrix and calcification." Seminars in Cell and Developmental Biology 46: 17-26. doi:10.1016/j.semcdb.2015.09.005.

Falkowski, P.G., and Z. Dubinsky. 1981. "Light-shade adaptation of Stylophora pistillata, a hermatypic coral from the Gulf of Eilat." Nature 289 (5794): 172-174.

Falkowski, P.G., Z. Dubinsky, L. Muscatine, and J.W. Porter. 1984. "Light and the bioenergetics of a symbiotic coral." BioScience 34 (11): 705-709.

Fan, T., and C. Dai. 2002. "Sexual reproduction of the reef coral Stylophora pistillata in southern Taiwan." Acta Oceanographica Taiwanica 40 (2): 107-120.

Fel, J.P., C. Lacherez, A. Bensetra, S. Mezzache, E. Béraud, M. Léonard, D. Allemand, and C. Ferrier-Pagès. 2019. "Photochemical response of the scleractinian coral Stylophora pistillata to some sunscreen ingredients." Coral Reefs 38 (1): 109-122. doi:10.1007/s00338-018-01759-4.

Ferrier-Pagès, C., J.P. Gattuso, S. Dallot, and J. Jaubert. 2000. "Effect of nutrient enrichment on growth and photosynthesis of the zooxanthellate coral Stylophora pistillata." Coral Reefs 19 (2): 103-113. doi:10.1007/s003380000078.

Ferrier-Pagès, C., F. Houlbrèque, E. Wyse, C. Richard, D. Allemand, and F. Boisson. 2005. "Bioaccumulation of zinc in the scleractinian coral Stylophora pistillata." Coral Reefs 24 (4): 636-645. doi:10.1007/s00338-005-0045-x.

Ferrier-Pagès, C., C. Rottier, E. Beraud, and O. Levy. 2010. "Experimental assessment of the feeding effort of three scleractinian coral species during a thermal stress: Effect on the rates of photosynthesis." Journal of Experimental Marine Biology and Ecology 390 (2). Elsevier B.V.: 118-124. doi:10.1016/j.jembe.2010.05.007.

Ferrier-Pagès, C., L. Sauzéat, and V. Balter. 2018. "Coral bleaching is linked to the capacity of the animal host to supply essential metals to the symbionts." Global Change Biology 24 (7): 3145-3157. doi:10.1111/gcb.14141.

Ferrier-Pagès, C., V. Schoelzke, J. Jaubert, L. Muscatine, and O. Hoegh-Guldberg. 2001. "Response of a scleractinian coral, Stylophora pistillata, to iron and nitrate enrichment." Journal of Experimental Marine Biology and Ecology 259 (2): 249261. doi:10.1016/S0022-0981(01)00241-6.

Ferrier-Pagès, C., J. Witting, E. Tambutté, and K.P. Sebens. 2003. "Effect of natural zooplankton feeding on the tissue and skeletal growth of the scleractinian coral Stylophora pistillata." Coral Reefs 22 (3): 229-240. doi:10.1007/ s00338-003-0312-7.

Fine, M., H. Gildor, and A. Genin. 2013. "A coral reef refuge in the Red Sea." Global Change Biology 19 (12): 3640-3647. doi:10.1111/gcb.12356.

Fishelson, L. 1971. "Ecology and distribution of the benthic fauna in the shallow waters of the Red Sea." Marine Biology: International Journal on Life in Oceans and Coastal Waters 10 (2): 113-133. doi:10.1007/BF00354828.

Fitt, W.K., R.D. Gates, O. Hoegh-Guldberg, J.C. Bythell, A. Jatkar, A.G. Grottoli, M. Gomez, et al. 2009. "Response of two species of Indo-Pacific corals, Porites cylindrica and Stylophora pistillata, to short-term thermal stress: The host does matter in determining the tolerance of corals to bleaching." Journal of Experimental Marine Biology and Ecology 373 (2). Elsevier B.V.: 102-110. doi:10.1016/j.jembe.2009.03.011.

Flot, J.F., J. Blanchot, L. Charpy, C. Cruaud, W.Y. Licuanan, Y. Nakano, C. Payri, and S. Tillier. 2011. "Incongruence 
between morphotypes and genetically delimited species in the coral genus Stylophora: phenotypic plasticity, morphological convergence, morphological stasis or interspecific hybridization?" BMC Ecology 11 (1). BioMed Central Ltd: 22. doi:10.1186/1472-6785-11-22.

Frank, U., U. Oren, Y. Loya, and B. Rinkevich. 1997. "Alloimmune maturation in the coral Stylophora pistillata is achieved through three distinctive stages, 4 months post-metamorphosis." Proceedings of the Royal Society of London: Series B: Biological Sciences 264 (1378): 99-104.

Frank, U., C. Rabinowitz, and B. Rinkevich. 1994. "In vitro establishment of continuous cell cultures and cell lines from ten colonial cnidarians." Marine Biology 120: 491-499.

Frank, U., and B. Rinkevich. 1994. "Nontransitive patterns of historecognition phenomena in the Red Sea hydrocoral Millepora dichotoma." Marine Biology 118 (4): 723-729. doi:10.1007/BF00347521.

Franklin, D.J., O. Hoegh-Guldberg, R.J. Jones, and J.A. Berges. 2004. "Cell death and degeneration in the symbiotic dinoflagellates of the coral Stylophora pistillata during bleaching." Marine Ecology Progress Series 272: 117-130. doi:10.3354/ meps 272117.

Furla, P., I. Galgani, I. Durand, and D. Allemand. 2000. "Sources and mechanisms of inorganic carbon transport for coral calcification and photosynthesis." Journal of Experimental Biology 203 (22): 3445-3457.

Ganot, P., E. Tambutté, N. Caminiti-Segonds, G. Toullec, D. Allemand, and S. Tambutté. 2020. "Ubiquitous macropinocytosis in anthozoans." ELife 9: 1-25. doi:10.7554/eLife.50022.

Garcia-Herrera, N., S.C.A. Ferse, A. Kunzmann, and A. Genin. 2017. "Mutualistic damselfish induce higher photosynthetic rates in their host coral." Journal of Experimental Biology 220 (10): 1803-1811. doi:10.1242/jeb.152462.

Gattuso, J.P., M. Frankignoulle, I. Bourge, S. Romaine, and R.W. Buddemeier. 1998. "Effect of calcium carbonate saturation of seawater on coral calcification." Global and Planetary Change 18 (1-2): 37-46. doi:10.1016/S09218181(98)00035-6.

Glynn, P.W. 1983. "Increased survivorship on corals harbouring crustacean symbionts." Marine Biology and Fisheries 4 (2): 105-111.

Goldshmid, R., R. Holzman, D. Weihs, and A. Genin. 2004. "Aeration of corals by sleep-swimming fish." Limnology and Oceanography 49 (5): 1832-1839. doi:10.4319/ lo.2004.49.5.1832.

Golomb, D., N. Shashar, and B. Rinkevich. 2020. "Coral carpets-A novel ecological engineering tool aimed at constructing coral communities on soft sand bottoms." Ecological Engineering 145 (February): 105743. doi:10.1016/j.ecoleng.2020.105743.

Grinblat, M., M. Fine, Y. Tikochinski, and Y. Loya. 2018. "Stylophora pistillata in the Red Sea demonstrate higher GFP fluorescence under ocean acidification conditions." Coral Reefs 37 (1). Springer Berlin Heidelberg: 309-320. doi:10.1007/ s00338-018-1659-0.

Grottoli, A.G., D. Tchernov, and G. Winters. 2017. "Physiological and biogeochemical responses of super-corals to thermal stress from the northern gulf of Aqaba, Red Sea." Frontiers in Marine Science 4 (July): 1-12. doi:10.3389/ fmars.2017.00215.

Grover, R., J.F. Maguer, D. Allemand, and C. Ferrier-page. 2006. "Urea uptake by the scleractinian coral Stylophora pistillata." Journal of Experimental Marine Biology and Ecology 332: 216-225. doi:10.1016/j.jembe.2005.11.020.

Grover, R., J.F. Maguer, D. Allemand, and C. Ferrier-Pagès. 2003. "Nitrate uptake in the scleractinian coral Stylophora pistillata." Limnology and Oceanography 48 (6): 2266-2274. doi:10.4319/lo.2003.48.6.2266.

Grover, R., J.F. Maguer, D. Allemand, and C. Ferrier-Pagès. 2008. "Uptake of dissolved free amino acids by the scleractinian coral Stylophora pistillata." Journal of Experimental Biology 211 (6): 860-865. doi:10.1242/jeb.012807.

Grover, R., J.F. Maguer, S. Reynaud-Vaganay, and C. FerrierPagès. 2002. "Uptake of ammonium by the scleractinian coral Stylophora pistillata: Effect of feeding, light, and ammonium concentrations." Limnology and Oceanography 47 (3): 782-790. doi:10.4319/lo.2002.47.3.0782.

Guerrini, G., M. Yerushalmy, D. Shefy, N. Shashar, and B. Rinkevich. 2020. "Apparent recruitment failure for the vast majority of coral species at Eilat, Red Sea." Coral Reefs. doi:10.1007/s00338-020-01998-4.

Gutner-Hoch, E., H.W. Ben-Asher, R. Yam, A. Shemesh, and O. Levy. 2017. "Identifying genes and regulatory pathways associated with the scleractinian coral calcification process." PeerJ 2017 (7): 3590. doi:10.7717/peerj.3590.

Hall, E.R., E.M. Muller, T. Goulet, J. Bellworthy, K.B. Ritchie, and M. Fine. 2018. "Eutrophication may compromise the resilience of the Red Sea coral Stylophora pistillata to global change." Marine Pollution Bulletin 131 (May). Elsevier: 701-711. doi:10.1016/j.marpolbul.2018.04.067.

Hasan, M.H. 2019. "Effect of hard installation on coral community succession and growth rate at taba heights international marina at the northern Gulf of Aqaba, Egypt." Egyptian Journal of Aquatic Biology and Fisheries 23 (3): 225-243. doi:10.21608/ejabf.2019.41918.

Hawkins, T.D., T. Krueger, S.P. Wilkinson, P.L. Fisher, and S.K. Davy. 2015. "Antioxidant responses to heat and light stress differ with habitat in a common reef coral." Coral Reefs 34 (4): 1229-1241. doi:10.1007/s00338-015-1345-4.

Hédouin, L., M. Metian, J.L. Teyssié, F. Oberhänsli, C. FerrierPagès, and M. Warnau. 2016. "Bioaccumulation of $63 \mathrm{Ni}$ in the scleractinian coral Stylophora pistillata and isolated Symbiodinium using radiotracer techniques." Chemosphere 156: 420-427. doi:10.1016/j.chemosphere.2016.04.097.

Heyward, A.J., and A.P. Negri. 1999. "Natural inducers for coral larval metamorphosis." Coral Reefs 18 (3): 273-279. doi:10.1007/s003380050193.

Heyward, A.J., and A.P. Negri. 2010. "Plasticity of larval pre-competency in response to temperature: Observations on multiple broadcast spawning coral species." Coral Reefs 29 (3): 631636. doi:10.1007/s00338-009-0578-5.

Hoegh-Guldberg, O., and J.G. Smith. 1989a. "Influence of the population density of zooxanthellae and supply of ammonium on the biomass and metabolic characteristics of the reef corals Seriatopora hystrix and Stylophora pistillata." Marine Ecology Progress Series 57 (October): 173-186. doi:10.3354/meps057173.

Hoegh-Guldberg, O., and J.G. Smith. 1989b. "The effect of sudden changes in temperature, light and salinity on the population density and export of zooxathellae from the reef corals Stylophora pistillata Esper and Seriatopora hystrix Dana." Genetics and Ceff Biology 129: 279-303.

Horoszowski-Fridman, Y., J.C. Brêthes, N. Rahmani, and B. Rinkevich. 2015. "Marine silviculture: Incorporating ecosystem engineering properties into reef restoration acts." Ecological Engineering 82. Elsevier B.V.: 201-213. doi:10.1016/j.ecoleng.2015.04.104.

Horoszowski-Fridman, Y., I. Izhaki, and B. Rinkevich. 2020. "Long-term heightened larval production in nursery-bred coral transplants." Basic and Applied Ecology: 0-25. doi:10.1016/j.baae.2020.05.003. 
Horoszowski-Fridman, Y., and B. Rinkevich. 2020. "Active coral reef restoration in Eilat, Israel: Reconnoitering the long-term prospectus." In Active Coral Restoration, ed. Vaughan, D. Platation, FL: J. Ross Publishing.

Horwitz, R., M.O. Hoogenboom, and M. Fine. 2017. "Spatial competition dynamics between reef corals under ocean acidification." Scientific Reports 7: 1-13. doi:10.1038/srep40288.

Houlbre'que, F., and C. Ferrier-page. 2009. "Heterotrophy in tropical scleractinian corals." Biological Reviews 84: 1-17. doi:10.1111/j.1469-185X.2008.00058.x.

Houlbrèque, F., E. Tambutté, D. Allemand, and C. Ferrier-Pagès. 2004. "Interactions between zooplankton feeding, photosynthesis and skeletal growth in the scleractinian coral Stylophora pistillata." Journal of Experimental Biology 207 (9): 1461-1469. doi:10.1242/jeb.00911.

Houlbrèque, F., E. Tambutté, and C. Ferrier-Pagès. 2003. "Effect of zooplankton availability on the rates of photosynthesis, and tissue and skeletal growth in the scleractinian coral Stylophora pistillata." Journal of Experimental Marine Biology and Ecology 296 (2): 145-166. doi:10.1016/ S0022-0981(03)00259-4.

Karako-Lampert, S., D. Zoccola, M. Salmon-Divon, M. Katzenellenbogen, S. Tambutté, A. Bertucci, O. HoeghGuldberg, E. Deleury, D. Allemand, and O. Levy. 2014. "Transcriptome analysis of the scleractinian coral Stylophora pistillata." PLoS One 9 (2). doi:10.1371/journal. pone.0088615.

Keshavmurthy, S., S.Y. Yang, A. Alamaru, Y.Y. Chuang, M. Pichon, D. Obura, S. Fontana, et al. 2013. "DNA barcoding reveals the coral 'laboratory-rat', Stylophora pistillata encompasses multiple identities." Scientific Reports 3: 1-7. doi:10.1038/srep01520.

Klueter, A., and N. Andreakis. 2013. "Assessing genetic diversity in the scleractinian coral Stylophora pistillata (Esper 1797) from the Central Great Barrier Reef and the Coral Sea." Systematics and Biodiversity 11 (1): 67-76. doi:10.1080/147 72000.2013.770419.

Kotb, M.M.A., and R.G. Hartnoll. 2002. "Aspects of the growth and reproduction of the coral gall crab Hapalocarcinus marsupialis." Journal of Crustacean Biology 22 (3): 558-566. doi:10.1651/0278-0372(2002)022[0558:aotgar]2.0.co;2.

Kramarsky-Winter, E., C.A. Downs, A. Downs, and Y. Loya. 2009. "Cellular responses in the coral Stylophora pistillata exposed to eutrophication from fish mariculture." Evolutionary Ecology Research 11 (3): 381-401.

Kramer, N., G. Eyal, R. Tamir, and Y. Loya. 2019. "Upper mesophotic depths in the coral reefs of Eilat, Red Sea, offer suitable refuge grounds for coral settlement." Scientific Reports 9 (1): 1-12. doi:10.1038/s41598-019-38795-1.

Krueger, T., N. Horwitz, J. Bodin, M.E. Giovani, S. Escrig, A. Meibom, and M. Fine. 2017. "Common reef-building coral in the northern red sea resistant to elevated temperature and acidification.” Royal Society Open Science 4 (5). doi:10.1098/ rsos. 170038 .

Kteifan, M., M. Wahsha, and F.A. Al-Horani. 2017. “Assessing stress response of Stylophora pistillata towards oil and phosphate pollution in the Gulf of Aqaba, using molecular and biochemical markers." Chemistry and Ecology 33 (4): 281294. doi:10.1080/02757540.2017.1308500.

Kücken, M., B. Rinkevich, L. Shaish, and A. Deutsch. 2011. "Nutritional resources as positional information for morphogenesis in the stony coral Stylophora pistillata." Journal of Theoretical Biology 275 (1): 70-77. doi:10.1016/j. jtbi.2011.01.018.

Kuwamura, T., Y. Yogo, and Y. Nakashima. 1994. "Population dynamics of goby Paragobiodon echinocephalus and host coral Stylophora pistillata." Marine Ecology Progress Series 103 (1-2): 17-24. doi:10.3354/meps103017.

Lampert-Karako, S., N. Stambler, D.J. Katcoff, Y. Achituv, Z. Dubinsky, and N. Simon-Blecher. 2008. "Effects of depth and eutrophication on the zooxanthella clades of Stylophora pistillata from the Gulf of Eilat (Red Sea)." Aquatic Conservetion: Marine and Fresh Water Ecosystems 18: 1039-1045. doi:10.1002/aqc.927 Effects.

Levy, O., L. Fernandes de Barros Marangoni, J.I. Cohen, C. Rottier, E. Béraud, R. Grover, and C. Ferrier-Pagès. 2020. "Artificial light at night (ALAN) alters the physiology and biochemistry of symbiotic reef building corals." Environmental Pollution 266: 114987. doi:10.1016/j.envpol.2020.114987.

Liberman, T., A. Genin, and Y. Loya. 1995. "Effects on growth and reproduction of the coral Stylophora pistillata by the mutualistic damselfish Dascyllus marginatus." Marine Biology 121 (4): 741-746. doi:10.1007/BF00349310.

Liew, Y.J., M. Aranda, A. Carr, S. Baumgarten, D. Zoccola, S. Tambutté, D. Allemand, G. Micklem, and C.R. Voolstra. 2014. "Identification of microRNAs in the coral Stylophora pistillata." PLoS One 9 (3): 1-11. doi:10.1371/journal. pone.0091101.

Liew, Y.J., D. Zoccola, Y. Li, E. Tambutte, A.A. Venn, C.T. Michell, G. Cui, et al. 2018. "Epigenome-associated phenotypic acclimatization to ocean acidification in a reef-building coral." Science Advances 4 (6). doi:10.1126/sciadv.aar8028.

Limviriyakul, P., L.C. Tseng, J.S. Hwang, and T.W. Shih. 2016. "Anomuran and brachyuran symbiotic crabs in coastal areas between the Southern Ryukyu arc and the coral triangle." Zoological Studies 55. doi:10.6620/ZS.2016.55-07.

Linden, B., J. Huisman, and B. Rinkevich. 2018. "Circatrigintan instead of lunar periodicity of larval release in a brooding coral species." Scientific Reports 8 (1): 1-9. doi:10.1038/ s41598-018-23274-w.

Linden, B., and B. Rinkevich. 2011. "Creating stocks of young colonies from brooding coral larvae, amenable to active reef restoration." Journal of Experimental Marine Biology and Ecology 398 (1-2): 40-46. doi:10.1016/j.jembe.2010.12.002.

Linden, B., and B. Rinkevich. 2017. "Elaborating an ecoengineering approach for stock enhanced sexually derived coral colonies." Journal of Experimental Marine Biology and Ecology 486 (October): 314-321. doi:10.1016/j. jembe.2016.10.014.

Linden, B., M.J.A. Vermeij, and B. Rinkevich. 2019. "The coral settlement box: A simple device to produce coral stock from brooded coral larvae entirely in situ." Ecological Engineering 132. Elsevier: 115-119. doi:10.1016/j. ecoleng.2019.04.012.

Loya, Y. 1976. "The Red Sea coral Stylophora pistillata is an $\mathrm{r}$ strategist." Nature 259: 478-480.

Loya, Y., and B. Rinkevich. 1979. "Abortion effect in corals induced by oil pollution.” Marine Ecology Progress Series 1: 77-80. doi:10.3354/meps001077.

Loya, Y., and B. Rinkevich. 1987. "Effects of petroleum hydrocarbons on corals." Human Impacts on Coral Reefs: Facts and Recommendations. French Polynesia: Antenne Museum EPHE, 91-102.

Malik, A., S. Einbinder, S. Martinez, D. Tchernov, S. Haviv, R. Almuly, P. Zaslansky, et al. 2020. "Molecular and skeletal fingerprints of scleractinian coral biomineralization: From the sea surface to mesophotic depths." Acta Biomaterialia, 1-14. doi:10.1016/j.actbio.2020.01.010.

Maor-Landaw, K., and O. Levy. 2016. "Gene expression profiles during short-term heat stress; branching vs. massive Scleractinian corals of the Red Sea." PeerJ 4(E1814). doi:10.7717/peerj.1814. 
Marsh, J.A. 1970. "Primary productivity of reef-building calcareous red algae.” Ecological Society of America 51 (2): 255-263.

Mass, T., J.L. Drake, L. Haramaty, Y. Rosenthal, O.M.E. Schofield, R.M. Sherrell, and P.G. Falkowski. 2012. "Aragonite precipitation by 'proto-polyps' in coral cell cultures." PLoS One 7 (4): 8-15. doi:10.1371/journal.pone.0035049.

Mass, T., J.L. Drake, J.M. Heddleston, and P.G. Falkowski. 2017a. "Nanoscale visualization of biomineral formation in coral proto-polyps." Current Biology 27 (20). Elsevier Ltd.: 31913196.e3. doi:10.1016/j.cub.2017.09.012.

Mass, T., J.L. Drake, E.C. Peters, W. Jiang, and P.G. Falkowski. 2014. "Immunolocalization of skeletal matrix proteins in tissue and mineral of the coral Stylophora pistillata." Proceedings of the National Academy of Sciences of the United States of America 111 (35): 12728-12733. doi:10.1073/pnas.1408621111.

Mass, T., A.J. Giuffre, C.Y. Sun, C.A. Stifler, M.J. Frazier, M. Neder, N. Tamura, C. V. Stan, M.A. Marcus, and P.U.P.A. Gilbert. 2017b. "Amorphous calcium carbonate particles form coral skeletons." Proceedings of the National Academy of Sciences of the United States of America 114 (37): E7670E7678. doi:10.1073/pnas.1707890114.

Mbije, N.E.J., J. Douek, E. Spanier, and B. Rinkevich. 2019. "Population genetic parameters of the emerging corallivorous snail Drupella cornus in the northern Gulf of Eilat and Tanzanian coastlines based on mitochondrial COI gene sequences." Marine Biodiversity 49: 147-161. doi:10.1007/ s12526-017-0768-2.

McCloskey, L.R., and L. Muscatine. 1984. "Production and respiration in the Red Sea coral Stylophora pistillata as a function of depth." Proceedings of the Royal Society of London: Series B, Biological Sciences 222 (1227): 215-230.

Metian, M., L. Hédouin, C. Ferrier-Pagès, J.L. Teyssié, F. Oberhansli, E. Buschiazzo, and M. Warnau. 2015. "Metal bioconcentration in the scleractinian coral Stylophora pistillata: Investigating the role of different components of the holobiont using radiotracers." Environmental Monitoring and Assessment 187 (4). doi:10.1007/s10661-015-4383-z.

Mohammed, T.A.A., and M.H. Yassien. 2013. "Assemblages of two gall crabs within coral species northern Red Sea, Egypt." Asian Journal of Scientific Research. doi:10.3923/ ajsr.2013.98.106.

Mokady, O., D.B. Bonar, G. Arazi, and Y. Loya. 1991. "Coral host specificity in settlement and metamorphosis of the date mussel Lithophaga lessepsiana (Vaillant, 1865)." Journal of Experimental Marine Biology and Ecology 146 (2): 205216. doi:10.1016/0022-0981(91)90026-S.

Mokady, O., D.B. Bonar, G. Arazi, and Y. Loya. 1993. "Spawning and development of three coral-associated Lithophaga species in the Red Sea." Marine Biology 115 (2): 245-252. doi:10.1007/BF00346341.

Mokady, O., S. Rozenblatt, D. Graur, and Y. Loya. 1994. "Coralhost specificity of Red Sea Lithophaga bivalves: Interspecific and intraspecific variation in $12 \mathrm{~S}$ mitochondrial ribosomal RNA." Molecular Marine Biology and Biotechnology 3 (3): 158-164.

Moya, A., S. Tambutté, E. Tambutté, D. Zoccola, N. Caminiti, and D. Allemand. 2006. "Study of calcification during a daily cycle of the coral Stylophora pistillata: Implications for "light-enhanced calcification.'” Journal of Experimental Biology 209 (17): 3413-3419. doi:10.1242/jeb.02382.

Muir, P.R., and M. Pichon. 2019. "Biodiversity of reef-building, scleractinian corals.” In Mesophotic Coral Ecosystems, eds. Loya, Y., Puglise, K.A., and Bridge, T.C.L., 589-620. Cham: Springer International Publishing. doi:10.1007/978-3-319-92735-0_33.
Müller, W.E.G., I. Müller, R. Zhan, and A. Maidhof. 1984. "Intraspecific recognition system in scleractinian corals: Morphological and cytochemical description of the autolysis mechanism." Journal of Histochemistry \& Cytochemistry 32 (3): 285-288.

Muscatine, L., P. Falkowski, J.W. Porter, and Z. Dubinsky. 1984. "Fate of photosynthetic fixed carbon in light-and shadeadapted colonies of the symbiotic coral Stylophora pistillata." Society of London: Series B: Biological Sciences 222 (1227): 181-202.

Muscatine, L., L.R. McCloskey, and Y. Loya. 1985. “A comparison of the growth rates of zooxanthellae and animal tissue in the red sea coral Stylophora pistillata." Proceedings of the Fifth International Coral Reef Congress, Tahiti, 6: 119-123.

Muscatine, L., L.R. Mccloskey, and R.E. Marian. 1981. "Estimating the daily contribution of carbon from zooxanthellae to coral animal respiration." Limnolgy and Oceanography 26 (4): 601-611.

Muscatine, L., J.W. Porter, and I.R. Kaplan. 1989. "Resource partitioning by reef corals as determined from stable isotope composition." Marine Biology 100: 185-193.

Muscatine, L., E. Tambutte, and D. Allemand. 1997. "Morphology of coral desmocytes, cells that anchor the calicoblastic epithelium to the skeleton." Coral Reefs 16 (4): 205-213. doi:10.1007/s003380050075.

Nakamura, T., H. Yamasaki, and R. Van Woesik. 2003. "Water flow facilitates recovery from bleaching in the coral Stylophora pistillata." Marine Ecology Progress Series 256: 287-291.

Nishikawa, A., M. Katoh, and K. Sakai. 2003. "Larval settlement rates and gene flow of broadcast-spawning (Acropora tenuis) and planula-brooding (Stylophora pistillata) corals." Marine Ecology Progress Series 256: 87-97. doi:10.3354/ meps256087.

Oren, M., K.O. Amar, J. Douek, T. Rosenzweig, G. Paz, and B. Rinkevich. 2010. "Assembled catalog of immune-related genes from allogeneic challenged corals that unveils the participation of vWF-like transcript." Developmental and Comparative Immunology 34 (6): 630-637. doi:10.1016/j. dci.2010.01.007.

Oren, M., G. Paz, J. Douek, A. Rosner, K.O. Amar, and B. Rinkevich. 2013. "Marine invertebrates cross phyla comparisons reveal highly conserved immune machinery." Immunobiology 218 (4): 484-495. doi:10.1016/j.imbio.2012.06.004.

Peled, Y., J.L. Drake, A. Malik, R. Almuly, M. Lalzar, D. Morgenstern, and T. Mass. 2020. "Optimization of skeletal protein preparation for LC-MS/MS sequencing yields additional coral skeletal proteins in Stylophora pistillata." BMC Materials 2 (1): 8. doi:10.1186/s42833-020-00014-x.

Pontasch, S., P.L. Fisher, T. Krueger, S. Dove, O. Hoegh-Guldberg, W. Leggat, and S.K. Davy. 2017. "Photoacclimatory and photoprotective responses to cold versus heat stress in high latitude reef corals." Journal of Phycology 53 (2): 308-321. doi:10.1111/jpy.12492.

Pratchett, M.S. 2001. "Influence of coral symbionts on feeding preferences of crown-of-thorns starfish Acanthaster planci in the Western Pacific." Marine Ecology Progress Series 214: 111-119. doi:10.3354/meps214111.

Puill-Stephan, E., M.J.H. van Oppen, K. Pichavant-Rafini, and B.L. Willis. 2012. "High potential for formation and persistence of chimeras following aggregated larval settlement in the broadcast spawning coral, Acropora millepora." Proceedings of the Royal Society of London: Series B: Biological Sciences 279 (1729): 699-708. doi:10.1098/rspb.2011.1035.

Putnam, H.M., P.J. Edmunds, and T.-Y. Fan. 2008. "Effect of temperature on the settlement choice and photophysiology 
of larvae from the reef coral Stylophora pistillata." The Biological Bulletin 215 (2): 135-142. doi:10.2307/25470694.

Puverel, S., F. Houlbrèque, E. Tambutté, D. Zoccola, P. Payan, N. Caminiti, S. Tambutté, and D. Allemand. 2007. "Evidence of low molecular weight components in the organic matrix of the reef building coral, Stylophora pistillata." Comparative Biochemistry and Physiology: A Molecular and Integrative Physiology 147 (4): 850-856. doi:10.1016/j. cbpa.2006.10.045.

Puverel, S., E. Tambutté, L. Pereira-Mouriès, D. Zoccola, D. Allemand, and S. Tambutté. 2005. "Soluble organic matrix of two Scleractinian corals: Partial and comparative analysis." Comparative Biochemistry and Physiology: B Biochemistry and Molecular Biology 141 (4): 480-487. doi:10.1016/j. cbpc.2005.05.013.

Rachmilovitz, E.N., and B. Rinkevich. 2017. "Tiling the reef: Exploring the first step of an ecological engineering tool that may promote phase-shift reversals in coral reefs." Ecological Engineering 105. Elsevier B.V.: 150-161. doi:10.1016/j. ecoleng.2017.04.038.

Rahav, O., Z. Dubinsky, Y. Achituv, and P.G. Falkowski. 1989. "Ammonium metabolism in the zooxanthellate coral, Stylophora pistillata." Proc. R. Soc. Lond. B 236: 325-337.

Raymundo, L.J., and A.P. Maypa. 2004. "Getting bigger faster: Mediation of size-specific mortality via fusion in juvenile coral transplants." Ecological Applications 14 (1): 281-295.

Raz-Bahat, M., J. Douek, E. Moiseeva, E.C. Peters, and B. Rinkevich. 2017. "The digestive system of the stony coral Stylophora pistillata." Cell and Tissue Research 368 (2): 311-323. doi:10.1007/s00441-016-2555-y.

Raz-Bahat, M., J. Erez, and B. Rinkevich. 2006. "In vivo light-microscopic documentation for primary calcification processes in the hermatypic coral Stylophora pistillata." Cell Tisue Res 325: 361-368. doi:10.1007/ s00441-006-0182-8.

Reynaud-Vaganay, S., A. Juillet-Leclerc, J. Jaubert, and J.P. Gattuso. 2001. "Effect of light on skeletal $\delta 13 \mathrm{C}$ and $\delta 180$, and interaction with photosynthesis, respiration and calcification in two zooxanthellate scleractinian corals." Palaeogeography, Palaeoclimatology, Palaeoecology. doi:10.1016/S0031-0182(01)00382-0.

Reynaud, S., N. Leclercq, S. Romaine-Lioud, C. Ferrier-Pagès, J. Jaubert, and J. Pierre-Gattuso. 2003. "Interacting effects of $\mathrm{CO}_{2}$ partial pressure and temperature on photosynthesis and calcification in a scleractinian coral." Global Change Biology 9: 1660-1668. doi:10.1046/j.1529-8817.2003.00678.x.

Richmond, R.H. 1997. "Reproduction and recruitment in corals: Critical links in the persistence of reefs." Life and Death of Coral Reefs, 175-197. New York: Chapman \& Hall.

Rinkevich, B. 1982. "Stylophora pistillata: Ecophysiological aspects in biology of an hermatypic coral." Tel-Aviv university, Tel-Aviv.

Rinkevich, B. 1989. "The contribution of photosynthetic products to coral reproduction." Marine Biology 101 (2): 259-263. doi:10.1007/BF00391465.

Rinkevich, B. 1991. "A long-term compartmental partitioning of photosynthetically fixed carbon in a symbiotic reef coral." Symbiosis 10: 175-194.

Rinkevich, B. 1995. "Restoration strategies for coral reefs damaged by recreational activities: The use of sexual and asexual recruits." Society for Ecological Restoration 3 (4): 241-251. doi:10.1111/j.1526-100X.1995.tb00091.x.

Rinkevich, B. 2000. "Steps towards the evaluation of coral reef restoration by using small branch fragments." Marine Biology 136 (5): 807-812. doi:10.1007/s002270000293.
Rinkevich, B. 2001. "Genetic regulation in the branching stony coral Stylophora pistillata." In The Algorithmic Beauty of Seaweeds, Sponges, and Corals, 62-66. Berlin: Springer.

Rinkevich, B. 2002. "The branching coral Stylophora pistillata: Contribution of genetics in shaping colony landscape." Israel Journal of Zoology 48 (1): 71-82. doi:10.1560/ bcpa-um3a-mkbp-hgl2.

Rinkevich, B. 2004. "Allorecognition and xenorecognition in reef corals: A decade of interactions." Hydrobiologia 530-531 (March): 443-450. doi:10.1007/s10750-004-2686-0.

Rinkevich, B. 2005. "Conservation of coral reefs through active restoration measures: Recent approaches and last decade progress." Environmental Science and Technology 39 (12): 4333-4342. doi:10.1021/es0482583.

Rinkevich, B. 2008. "Management of coral reefs: We have gone wrong when neglecting active reef restoration." Marine Pollution Bulletin 56 (11). Elsevier Ltd: 1821-1824. doi:10.1016/j.marpolbul.2008.08.014.

Rinkevich, B. 2011. "Quo vadis chimerism?" Chimerism 2 (1): 1-5. doi:10.4161/chim.2.1.14725.

Rinkevich, B. 2012. "Neglected biological features in Cnidarians self-nonself recognition.” In Self-NonSelf Recognition, ed. López-Larrea, C., 46-59. New York: Springer.

Rinkevich, B. 2014. "Rebuilding coral reefs: Does active reef restoration lead to sustainable reefs?" Current Opinion in Environmental Sustainability 7: 28-36. doi:10.1016/j. cosust.2013.11.018.

Rinkevich, B. 2015a. "Novel tradable instruments in the conservation of coral reefs, based on the coral gardening concept for reef restoration." Journal of Environmental Management 162: 199-205. doi:10.1016/j.jenvman.2015.07.028.

Rinkevich, B. 2015b. "Climate change and active reef restorationways of constructing the 'reefs of tomorrow'." Journal of Marine Science and Engineering 3 (1): 111-127. doi:10.3390/jmse3010111.

Rinkevich, B. 2015c. "A critique of why looks can be deceptive in judging the health of well-fed corals (related to DOI 10.1002/ bies.201400074)." BioEssays 37 (4): 354-355. doi:10.1002/ bies.201400216.

Rinkevich, B. 2019a. "The active reef restoration toolbox is a vehicle for coral resilience and adaptation in a changing world." Journal of Marine Science and Engineering 7: 201. doi:10.3390/jmse7070201.

Rinkevich, B. 2019b. "Coral chimerism as an evolutionary rescue mechanism to mitigate global climate change impacts." Global Change Biology 25 (4): 1198-1206. doi:10.1111/ gcb.14576.

Rinkevich, B. 2020. "Ecological engineering approaches in coral reef restoration." ICES Journal of Marine Science 2100. doi:10.1093/icesjms/fsaa022.

Rinkevich, B., S. Ben-Yakir, and R. Ben-Yakir. 1999. "Regeneration of amputated avian bone by a coral skeletal implant." Biological Bulletin 197 (1): 11-13.

Rinkevich, B., and Y. Loya. 1977. "Harmful effects of chronic oil pollution on a Red Sea scleractinian coral population." Proceedings of the Third Internacional Coral Reef Symposium. Miami.

Rinkevich, B., and Y. Loya. 1979a. "The reproduction of the Red Sea coral Stylophora pistillata. I: Gonads and planulae." Marine Ecology Progress Series 1: 145-152. doi:10.3354/ meps001145.

Rinkevich, B., and Y. Loya. 1979b. "The reproduction of the Red Sea coral Stylophora pistillata. II: Synchronization in breeding and seasonality of planulae shedding." Marine Ecology Progress Series 1: 133-144. doi:10.3354/meps001133. 
Rinkevich, B., and Y. Loya. 1979c. "Laboratory experiments on the effects of crude oil on the Red Sea coral Stylophora pistillata." Marine Pollution Bulletin 10 (11): 328-330. doi:10.1016/0025-326X(79)90402-8.

Rinkevich, B., and Y. Loya. 1983a. "Intraspecific competitive networks in the Red Sea coral Stylophora pistillata." Coral Reefs 1 (3): 161-172. doi:10.1007/BF00571193.

Rinkevich, B., and Y. Loya. 1983b. "Oriented translocation of energy in grafted reef corals." Coral Reefs 1 (4): 243-247. doi:10.1007/BF00304422.

Rinkevich, B., and Y. Loya. 1983c. "Short-term fate of photosynthetic products in a hermatypic coral." Journal of Experimental Marine Biology and Ecology 13: 175-184.

Rinkevich, B., and Y. Loya. 1984a. "Coral illumination through an optic glass-fiber: Incorporation of $14 \mathrm{C}$ photosynthates." Marine Biology 80: 7-15. doi:10.1038/164914a0.

Rinkevich, B., and Y. Loya. 1984b. "Does light enhance calcification in hermatypic corals?" Marine Biology 80 (1): 1-6. doi:10.1007/BF00393120.

Rinkevich, B., and Y. Loya. 1985a. "Coral isomone: A proposed chemical signal controlling intraclonal growth patterns in a branching coral." Bulletin of Marine Science 36 (2): 319-324.

Rinkevich, B., and Y. Loya. 1985b. "Intraspecific competition in a reef coral: Effects on growth and reproduction." Oecologia 66 (1): 100-105. doi:10.1007/BF00378559.

Rinkevich, B., and Y. Loya. 1986. "Senescence and dying signals in a reef building coral." Experientia 42: 320-322.

Rinkevich, B., and Y. Loya. 1987. "Variability in the pattern of sexual reproduction of the coral Stylophora pistillata at Eilat, Red Sea: A long-term study." Biological Bulletin 173 (2): 335. doi:10.2307/1541546.

Rinkevich, B., A. Nanthawan, and C. Rabinowitz. 2005. "UV incites diverse levels of DNA breaks in different cellular compartments of a branching coral species." Journal of Experimental Biology 208 (5): 843-848. doi:10.1242/jeb.01496.

Rinkevich, B., and S. Shafir. 1998. "Ex situ culture of colonial marine ornamental invertebrates: Concepts for domestication." Aquarium Sciences and Conservation 2: 237-250.

Rinkevich, B., N. Shashar, and T. Liberman. 1993. "Nontransitive xenogeneic interactions between four common Red Sea sessile invertebrates." Proceedings of the Seventh International Coral Reef Symposium 2: 833-839.

Rinkevich, B., and I.L. Weissman. 1987. "Chimeras in colonial invertebrates: A synergistic symbiosis or somatic-cell and germ-cell parasitism?" Symbiosis 4 (1-3): 117-134.

Rinkevich, B., Z. Wolodarsky, and Y. Loya. 1991. "Coral-crab association: A compact domain of a multilevel trophic system." Hydrobiologia 216-217 (1): 279-284. doi:10.1007/ BF00026475.

Rinkevich, Y., V. Matranga, and B. Rinkevich. 2009. "Stem cells in aquatic invertebrates: Common premises and emerging unique themes." In Stem Cells in Marine Organisms, eds. Rinkevich, B. and Matranga, V., 61-103. Dordrecht: Springer Netherlands. doi:10.1007/978-90-481-2767-2_4.

Rosic, N., C. Rémond, and M.A. Mello-Athayde. 2020. "Differential impact of heat stress on reef-building corals under different light conditions." Marine Environmental Research 158. doi:10.1016/j.marenvres.2020.104947.

Sampayo, E.M., T. Ridgway, P. Bongaerts, and O. HoeghGuldberg. 2008. "Bleaching susceptibility and mortality of corals are determined by fine-scale differences in symbiont type." Proceedings of the National Academy of Sciences of the United States of America 105 (30): 10444-10449. doi:10.1073/pnas.0708049105.
Sampayo, E.M., T. Ridgway, L. Franceschinis, G. Roff, and O. Hoegh-Guldberd. 2016. "Coral symbioses under prolonged environmental change: Living near tolerance range limits." Scientific Reports 6 (1): 1-12. doi:10.1038/srep36271.

Saragosti, E., D. Tchernov, A. Katsir, and Y. Shaked. 2010. "Extracellular production and degradation of superoxide in the coral Stylophora pistillata and cultured Symbiodinium." PLoS One 5 (9): 1-10. doi:10.1371/journal.pone.0012508.

Sawall, Y., M.C. Teichberg, J. Seemann, M. Litaay, J. Jompa, and C. Richter. 2011. "Nutritional status and metabolism of the coral Stylophora subseriata along a eutrophication gradient in Spermonde Archipelago (Indonesia)." Coral Reefs 30 (3): 841-853. doi:10.1007/s00338-011-0764-0.

Scucchia, F., H. Nativ, M. Neder, G. Goodbody-Gringley, and T. Mass. 2020. "Physiological characteristics of Stylophora pistillata larvae across a depth gradient." Frontiers in Marine Science 7 (January): 1-9. doi:10.3389/fmars.2020.00013.

Sevilgen, D.S., A.A. Venn, M.Y. Hu, E. Tambutté, D. De Beer, V. Planas-Bielsa, and S. Tambutté. 2019. "Full in vivo characterization of carbonate chemistry at the site of calcification in corals." Science Advances 5 (1): 1-10. doi:10.1126/sciadv.aau7447.

Shafir, S., S. Abady, and B. Rinkevich. 2009. "Improved sustainable maintenance for mid-water coral nursery by the application of an anti-fouling agent." Journal of Experimental Marine Biology and Ecology Improv 368: 124-128. doi:10.1016/j. jembe.2008.08.017.

Shafir, S., O. Gur, and B. Rinkevich. 2008. "A Drupella cornus outbreak in the northern Gulf of Eilat and changes in coral prey." Coral Reefs 27 (2): 379. doi:10.1007/s00338-008-0353-z.

Shafir, S., I. Halperin, and B. Rinkevich. 2014. "Toxicology of household detergents to reef corals." Water, Air, and Soil Pollution 225 (3). doi:10.1007/s11270-014-1890-4.

Shafir, S., and B. Rinkevich. 2008. "The underwater silviculture approach for reef restoration: An emergent aquaculture theme." In Aquaculture Research Trends, ed. Schwartz, S.H., 279-295. New York: Nova Science Publishers, Inc.

Shafir, S., and B. Rinkevich. 2010. "Integrated long-term midwater coral nurseries: A management instrument evolving into a floating ecosystem." University of Mauritius Research Journal 16: 365-386.

Shafir, S., J. Van Rijn, and B. Rinkevich. 2001. "Nubbing of coral colonies: A novel approach for the development of inland broodstocks." Aquarium Sciences and Conservation 3: 183-190.

Shafir, S., J. Van Rijn, and B. Rinkevich. 2003. "The use of coral nubbins in coral reef ecotoxicology testing." Biomolecular Engineering 20: 401-406. doi:10.1016/S1389-0344(03)00062-5.

Shafir, S., J. Van Rijn, and B. Rinkevich. 2006a. "A mid-water coral nursery." In Proceeding of 10th International Coral Reef Symposium, 1674-1679. Okinawa, Japan: International Society for Reef Stusied.

Shafir, S., J. Van Rijn, and B. Rinkevich. 2006b. "Steps in the construction of underwater coral nursery, an essential component in reef restoration acts." Marine Biology 149 (3): 679-687. doi:10.1007/s00227-005-0236-6.

Shafir, S., J. Van Rijn, and B. Rinkevich. 2007. "Short and long term toxicity of crude oil and oil dispersants to two representative coral species." Environmental Science and Technology 41 (15): 5571-5574. doi:10.1021/es0704582.

Shaish, L., A. Abelson, and B. Rinkevich. 2006. "Branch to colony trajectory in a modular organism: Pattern formation in the Indo-Pacific coral Stylophora pistillata." Developmental Dynamics 235 (8). Wiley Online Library: 2111-2121.

Shaish, L., A. Abelson, and B. Rinkevich. 2007. "How plastic can phenotypic plasticity be? The branching coral Stylophora 
pistillata as a model system." PLoS One 2 (7): 1-9. doi:10.1371/journal.pone.0000644.

Shaish, L., and B. Rinkevich. 2009. "Critical evaluation of branch polarity and apical dominance as dictators of colony astogeny in a branching coral." PLoS One 4 (1). doi:10.1371/journal.pone.0004095.

Shaked, Y., and A. Genin. 2019. The Israel National Monitoring Program in the Northern Gulf of Aqaba 2018. Jerusalem.

Shashar, N., Y. Cohen, and Y. Loya. 1993. "Extreme diel fluctuations of oxygen in diffusive boundary layers surrounding stony corals." The Biological Bulletin 185 (3): 455-461. doi:10.2307/1542485.

Shefy, D., N. Shashar, and B. Rinkevich. 2018. "The reproduction of the Red Sea coral Stylophora pistillata from Eilat: 4-decade perspective." Marine Biology 165 (2): 27. doi:10.1007/ s00227-017-3280-0.

Shick, J.M., S. Romaine-Lioud, C. Ferrier-Pagès, and J.P. Gattuso. 1999. "Ultraviolet-B radiation stimulates shikimate pathwaydependent accumulation of mycosporine-like amino acids in the coral Stylophora pistillata despite decreases in its population.” Limnology and Oceanography 44 (7): 1667-1682.

Shick, J.M., M.L. Wells, C.G. Trick, and W.C. Dunlap. 2011. "Responces to iron limitation in two colonies of Stylophora pistillata exposed to high temperature: Implications for coral bleaching." Limnology and Oceanography 56 (3): 813-828. doi:10.4319/LO.2011.56.3.0813.

Shlesinger, T., and Y. Loya. 2016. "Recruitment, mortality, and resilience potential of scleractinian corals at Eilat, Red Sea." Coral Reefs 35 (4): 1-12. doi:10.1007/s00338-016-1468-2.

Stambler, N., and N. Shashar. 2007. "Variation in spectral reflectance of the hermatypic corals, Stylophora pistillata and Pocillopora damicornis." Journal of Experimental Marine Biology and Ecology 351 (1): 143-149.

Stat, M., W.K.W. Loh, T.C. LaJeunesse, O. Hoegh-Guldberg, and D.A. Carter. 2009. "Stability of coral-endosymbiont associations during and after a thermal stress event in the southern Great Barrier Reef." Coral Reefs 28 (3): 709-713. doi:10.1007/s00338-009-0509-5.

Stefani, F., F. Benzoni, S.Y. Yang, M. Pichon, P. Galli, and C.A. Chen. 2011. "Comparison of morphological and genetic analyses reveals cryptic divergence and morphological plasticity in Stylophora (Cnidaria, Scleractinia)." Coral Reefs 30 (4): 1033-1049. doi:10.1007/s00338-011-0797-4.

Stimson, J., and R.A. Kinzie. 1991. "The temporal pattern and rate of release of zooxanthellae from the reef coral Pocillopora damicornis (Linnaeus) under nitrogen-enrichment and control conditions." Journal of Experimental Marine Biology and Ecology 153: 63-67.

Sun, C.-Y., L. Gránásy, C.A. Stifler, T. Zaquin, R. V. Chopdekar, N. Tamura, J.C. Weaver, et al. 2020. "Crystal nucleation and growth of spherulites demonstrated by coral skeletons and phase-field simulations." Acta Biomaterialia. doi:10.1016/j. actbio.2020.06.027.

Sun, C.-Y., M.A. Marcus, M.J. Frazier, A.J. Giuffre, T. Mass, and P.U.P.A. Gilbert. 2017. "Spherulitic growth of coral skeletons and synthetic aragonite: Nature's three-dimensional printing." ACS Nano 11 (7): 6612-6622. doi:10.1021/acsnano.7b00127.

Takabayashi, M., D.A. Carter, J. V. Lopez, and O. Hoegh-Guldberg. 2003. "Genetic variation of the scleractinian coral Stylophora pistillata, from western Pacific reefs." Coral Reefs 22 (1): 17-22. doi:10.1007/s00338-002-0272-3.

Tambutté, É., D. Allemand, E. Mueller, and J. Jaubert. 1996. “A compartmental approach to the mechanism of calcification in hermatypic corals." Journal of Experimental Biology 199 (5): 1029-1041.
Tambutté, É., A. D. D. Zoccola, A. Meibom, S. Lotto, N. Caminiti, and S. Tambutté. 2007. "Observations of the tissue-skeleton interface in the scleractinian coral Stylophora pistillata." Coral Reefs 205: 517-529. doi:10.1007/s00338-007-0263-5.

Tambutté, É., S. Tambutté, N. Segonds, D. Zoccola, A. Venn, J. Erez, and D. Allemand. 2012. "Calcein labelling and electrophysiology: Insights on coral tissue permeability and calcification." Proceedings of the Royal Society B: Biological Sciences 279 (1726): 19-27. doi:10.1098/rspb.2011.0733.

Tamir, R., G. Eyal, I. Cohen, and Y. Loya. 2020. "Effects of light pollution on the early life stages of the most abundant northern red sea coral." Microorganisms 8 (2). doi:10.3390/ microorganisms 8020193.

Tamir, R., A. Lerner, C. Haspel, Z. Dubinsky, and D. Iluz. 2017. "The spectral and spatial distribution of light pollution in the waters of the northern Gulf of Aqaba (Eilat)." Scientific Reports 7: 42329. doi:10.1038/srep42329.

Tanner, J.E. 1996. "Seasonality and lunar periodicity in the reproduction of Pocilloporid corals." Coral Reefs 15 (1): 59-66. doi:10.1007/s003380050028.

Tchernov, D., M.Y. Gorbunov, C. De Vargas, S.N. Yadav, A.J. Milligant, M. Häggblom, and P.G. Falkowski. 2004. "Membrane lipids of symbiotic algae are diagnostic of sensitivity to thermal bleaching in corals." Proceedings of the National Academy of Sciences of the United States of America 101 (37): 13531-13535. doi:10.1073/pnas.0402907101.

Titlyanov, E.A., K. Bil', I. Fomina, T. Titlyanova, V. Leletkin, N. Eden, A. Malkin, and Z. Dubinsky. 2000a. "Effects of dissolved ammonium addition and host feeding with Artemia salina on photoacclimation of the hermatypic coral Stylophora pistillata." Marine Biology 137 (3): 463-472. doi:10.1007/s002270000370.

Titlyanov, E.A., T. V Titlyanova, K. Yamazato, and R. Van Woesik. 2001. "Photo-acclimation of the hermatypic coral Stylophora pistillata while subjected to either starvation or food provisioning." Journal of Experimental Marine Biology and Ecology 257 (2001): 163-181.

Titlyanov, E.A., J. Tsukahara, T. V Titlyanova, V.A. Leletkin, R. Van Woesik, and K. Yamazato. 2000b. "Zooxanthellae population density and physiological state of the coral Stylophora pistillata during starvation and osmotic shock." Symbiosis 28: 303-322.

Tremblay, P., R. Grover, J.F. Maguer, M. Hoogenboom, and C. Ferrier-Pagès. 2014. "Carbon translocation from symbiont to host depends on irradiance and food availability in the tropical coral Stylophora pistillata." Coral Reefs 33 (1): 1-13. doi:10.1007/s00338-013-1100-7.

Venn, A., E. Tambutté, M. Holcomb, D. Allemand, and S. Tambutté. 2011. "Live tissue imaging shows reef corals elevate $\mathrm{pH}$ under their calcifying tissue relative to seawater." PLoS One 6 (5). doi:10.1371/journal.pone.0020013.

Veron, J.E.N. 2000. "Corals of the World, vol. 1-3." Australian Institute of Marine Science 58-63. Townsville.

Villanueva, R., H. Yap, and M. Montaño. 2008. "Timing of planulation by pocilloporid corals in the northwestern Philippines." Marine Ecology Progress Series 370 (October): 111-119. doi:10.3354/meps07659.

Von Euw, S., Q. Zhang, V. Manichev, N. Murali, J. Gross, L.C. Feldman, T. Gustafsson, C. Flach, R. Mendelsohn, and P.G. Falkowski. 2017. "Biological control of aragonite formation in stony corals.” Science 356 (6341): 933-938. doi:10.1126/ science.aam6371.

Voolstra, C.R., Y. Li, Y.J. Liew, S. Baumgarten, D. Zoccola, J.F. Flot, S. Tambutté, D. Allemand, and M. Aranda. 2017. "Comparative analysis of the genomes of Stylophora pistillata and Acropora 
digitifera provides evidence for extensive differences between species of corals." Scientific Reports 7 (1): 1-14. doi:10.1038/ s41598-017-17484-x.

Wallace, C.C., and P.L. Harrison. 1990. "Reproduction, dispersal and recruitment of scleractinian corals." In Ecosystems of the World, 25: Coral Reefs, ed. Dubinsky, Z., 25:133-207. Amsterdam: Coral Reefs. Elsevier Science Publishing Company, Inc.

Weis, V.M., G.J. Smith, and L. Muscatine. 1989. 'A ' $\mathrm{CO}_{2}$ supply' mechanism in zooxanthellate cnidarians: Role of carbonic anhydrase." Marine Biology 100: 195-202.

Winters, G., S. Beer, B. Ben Zvi, I. Brickner, and Y. Loya. 2009. "Spatial and temporal photoacclimation of Stylophora pistillata: Zooxanthella size, pigmentation, location and clade." Marine Ecology Progress Series 384: 107-119. doi:10.3354/ meps08036.

Yakovleva, I., R. Bhagooli, A. Takemura, and M. Hidaka. 2004. "Differential susceptibility to oxidative stress of two scleractinian corals: Antioxidant functioning of mycosporineglycine." Comparative Biochemistry and Physiology: B Biochemistry and Molecular Biology 139 (4): 721-730. doi:10.1016/j.cbpc.2004.08.016.

Zakai, D., Z. Dubinsky, A. Avishai, T. Caaras, and N. Chadwick. 2006. "Lunar periodicity of planula release in the reef-building coral Stylophora pistillata." Marine Ecology Progress Series 311: 93-102. doi:10.3354/meps311093.

Zoccola, D., P. Ganot, A. Bertucci, N. Caminiti-Segonds, N. Techer, C.R. Voolstra, M. Aranda, et al. 2015. "Bicarbonate transporters in corals point towards a key step in the evolution of cnidarian calcification." Scientific Reports 5: 1-11. doi:10.1038/srep09983.

Zoccola, D., E. Tambutté, E. Kulhanek, S. Puverel, J.C. Scimeca, D. Allemand, and S. Tambutté. 2004. "Molecular cloning and localization of a PMCA P-type calcium ATPase from the coral Stylophora pistillata." Biochimica et Biophysica Acta-Biomembranes 1663 (1-2): 117-126. doi:10.1016/j. bbamem.2004.02.010.

Zoccola, D., E. Tambutté, F. Sénégas-Balas, J.F. Michiels, J.P. Failla, J. Jaubert, and D. Allemand. 1999. "Cloning of a calcium channel $\alpha 1$ subunit from the reef-building coral, Stylophora pistillata." Gene 227 (2): 157-167. doi:10.1016/ S0378-1119(98)00602-7.

Zvuloni, A., O. Mokady, M. Al-Zibdah, G. Bernardi, S.D. Gaines, and A. Abelson. 2008. "Local scale genetic structure in coral populations: A signature of selection." Marine Pollution Bulletin 56 (3): 430-438. doi:10.1016/j.marpolbul. 2007.11.002. 